UNITED STATES

DEPARTMENT OF THE INTERIOR

GEOLOGICAL SURVEY

WATER RESOURCES OF ROCKLAND BASIN,

SOUTHEASTERN IDAHO

By R. P. Williams and H. W. Young

U.S. GEOLOGICAL SURVEY

Open-File Report $82-755$

Prepared in cooperation with the

Idaho Department of Water Resources

Boise, Idaho

December 1982 
Abstract-1-

Introduction- 2

Purpose-- A 2

Acknowledgments-- 4

Well- and spring-numbering system-- 4

Gaging-station numbering system- 4

Hydrologic setting

Topography and drainage- 6

Climate-- 1 - 6

Geology-

Water resources

Water yield-- 13

Surface water--

Annual discharge-- 17

Daily discharge-n 20

Peak runoff-_- 23

Ground water

Occurrence-- 23

Source and movement- 26

Water-level fluctuations---

Aquifer characteristics-- 35

Underflow-

Water use--

Consumptive water use and net irrigation •

requirements-- 38

Surface-water use-- 40

Ground-water use-- 41

Municipal, domestic, and stock water use-- 42

water budget-- 42

Surface-water/ground-water relations-- 43

Gaining and losing reaches in Rock Creek and

East Fork Rock Creek-_. 43

Effects of ground-water pumpage on surface-

water flows-- 44

Ground-water recharge from floods-- 49

Water quality- 50

Surface water--

Ground water-_- 54

Suggestions for monitoring

Summary--

Selected references-- 


\section{ILLUSTRATIONS}

$\underline{\text { Page }}$

FIGURE 1. Index map of study area and vicinity----- 3

2. Diagram showing well- and springnumbering system---- 5

3. Map showing distribution of precipitation and agricultural land use-- 8

4. Graph showing estimated precipitationaltitude relation-- 10

5. Graph showing cumulative departure of yearly precipitation for the period 1950-79 from the long-term mean-------

6. Map showing generalized geology---------

7. Diagram showing generalized geohydrologic section-..- 14

8. Graph showing estimated water yield------

9. Map showing locations of measuring

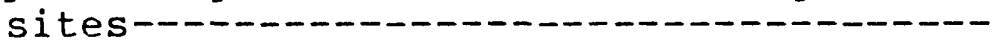

10. Graph showing mean daily discharge in Rock Creek near American Falls and in East Fork Rock Creek near Rockland, 1979 water year-........

11. Graph showing flow-duration curves for Rock Creek and East Fork Rock Creek for periods of record----

12. Map showing water-table contours and well locations-- 28

13. Hydrographs of ground-water levels in observation wells_... 32

14. Hydrographs of ground-water levels in selected wells... 33

15. Graph showing water-level fluctuations in observation well 11S-3IE-2lADDI caused by flood recharge---

16. Graph showing agricultural land use in Power County--

17. Map showing discharges and locations of inflow and outflow measuring sites-- - - - - - - - -

18. Graph showing effects of ground-water pumpage on streamflow at selected distances from Rock Creek-----_----

19. Map showing chemical character of water-- 


\section{TABLES}

Page

TABLE 1. Estimated water yields in southeastern

Idaho basins- 18

2. Measured peak discharges at selected

sites-_-

3. Estimated peak discharges at selected

stream sites-

4. Records of wells_._. 30

5. Chemical analyses of water--_- 51

6. Suspended-sediment discharge during

storm runoff of January $12-17$, 1980-..-

52 


\section{CONVERSION FACTORS}

For the convenience of those who prefer SI (International System of Units) rather than the inch-pound system, conversion factors for terms used in this report are listed below. Constituent concentrations are given in $\mathrm{mg} / \mathrm{L}$ (milligrams per liter) or $\mu \mathrm{g} / \mathrm{L}$ (micrograms per liter), which are equal to parts per million or parts per billion, respectively. Specific conductance is expressed as $\mu$ mho/cm (micromhos per centimeter at 25 degrees Celsius). Dissolved-solids concentrations reported in ton/acre-ft are equal to $0.00136 \mathrm{mg} / \mathrm{L}$.

Multiply inch-pound unit

inch (in.)

foot (ft)

mile ( $\mathrm{mi}$ )

acre

square mile $\left(\mathrm{mi}^{2}\right)$

$$
\begin{aligned}
& \text { gallon (gal) } \\
& \text { acre-foot (acre-ft) } \\
& \text { cubic foot per second } \\
& \text { (ft /s) } \\
& \text { gallon per day (gal/d) } \\
& \text { gallon per minute } \\
& \text { (gal/min) }
\end{aligned}
$$

By

\section{Length}

$$
\begin{gathered}
25.40 \\
0.3048 \\
1.609
\end{gathered}
$$

\section{Area}

4047

2.590

Volume

1234

3.785

Flow

0.02832

$4.381 \times 10^{-8}$

$6.309 \times 10^{-5}$
To obtain SI unit millimeter

meter

$\mathrm{kilometer}$

square meter

square kilometer

Iiter.

cubic meter

\section{Mass Per Unit Time}

ton per day (ton/d)

0.9072

megagram per day

Transmissivity

foot squared per day $\left(f t^{2} / d\right.$ )

0.0929

meter squared per day

\section{Specific Conductance}

micromho ( $\left.\mu^{\mathrm{mho}}\right)$

1.00

microsiemen 
Temperature

Conversion of ${ }^{\circ} \mathrm{C}$ to ${ }^{\circ} \mathrm{F}$ is by the equation ${ }^{\circ} \mathrm{F}=(1.8)\left({ }^{\circ} \mathrm{C}\right)+$ 32. Water temperatures are reported to the nearest 0.5 degree. 


\title{
WATER RESOURCES OF ROCKLAND BASIN, SOUTHEASTERN IDAHO
}

\section{By}

\author{
R. P. Williams and H. W. Young
}

\section{ABSTRACT}

Rockland basin comprises about 320 square miles of the Snake River drainage in southeastern Idaho. Mountain ranges bordering the basin are composed predominantly of limestone and are complexly faulted. Major aquifers include Holocene alluvium, Quaternary-Tertiary volcanic rocks, and Tertiary sedimentary rocks. Ground water occurs under water-table conditions except where it is locally confined. Ground water discharges to springs in the Deep Creek Mountains and maintains perennial streamflow. Near the mouth of Rock Creek, ground-water movement is northward toward the snake River. Underflow is estimated to be 51,000 acre-feet per year.

Total water yield available to Rockland basin is estimated to be 5.0 inches $(85,000$ acre-feet) of the estimated 17.3 inches of annual precipitation. Evapotranspiration ranges from 9.9 to 17 inches per year, depending, in part, on altitude of the land surface.

An estimated 12,000 acre-feet of surface water and 3,500 acre-feet of ground water are used annually for irrigation. Less than 100 acre-feet of water is used for public supply, domestic, and stock supplies. East Fork Rock Creek supplies the most surface water for irrigation of agricultural lands.

At the present (1980) state of ground-water development in Rockland basin, streams and aquifers are hydraulically connected. Pumping of ground water in increased quantities from wells near streams will affect ground-water movement and may diminish streamflow. There are no long-term regional water-table declines at the present time. Continued water-level monitoring of selected wells may aid in documenting effects of future management practices on the ground-water system. 


\section{INTRODUCTION}

Rockland basin comprises an area of about $320 \mathrm{mi}^{2}$ in southeastern Idaho (fig. 1). The basin is inhabited by fewer than 400 persons. The principal town is Rockland, with a population of $283(1980)$. The basic economy in the basin is agriculture, using both dryland and irrigated farming practices.

Prior to about 1950, irrigators in the basin depended almost entirely on diversions of surface water from Rock, South Fork Rock, and East Fork Rock Creeks. Irrigated acreage was limited primarily to lowlands adjacent to these creeks, where surface water could be diverted by gravity flow. The increase in the amount of irrigated acreage was restricted by the amount of flow in the creeks and the amount of ground-water discharge from a number of relatively small perennial springs scattered throughout the central and eastern parts of the basin. Also, a small amount of spring discharge was collected in ponds for watering of stock.

Since the early $1950^{\prime} \mathrm{s}$, irrigation of agricultural lands from surface water has been supplemented by an increasing amount of ground water. Development of ground water has resulted in expanded acreage of irrigated lands. Landowners consequently are interested in the future availability of water and the effects the increase in groundwater pumping might have on the amount of surface water and spring flow available for development. Historic hydrologic data collected on streamflow and water-level fluctuations in wells and the limited understanding of the interconnection between the surface-water and ground-water systems in the basin are not sufficient to provide answers to these questions.

\section{Purpose}

The purpose of this 2-year study was to document and describe the present (1980) water-resource conditions in Rockland basin so that management decisions can be made to optimize use of the water resources in the basin. Objectives of the report are to: (1) Describe the geology and hydrology, (2) estimate a water budget and water yield, (3) evaluate present water-resource development, (4) describe the interrelation between ground water and surface water, and (5) evaluate water-quality conditions. 


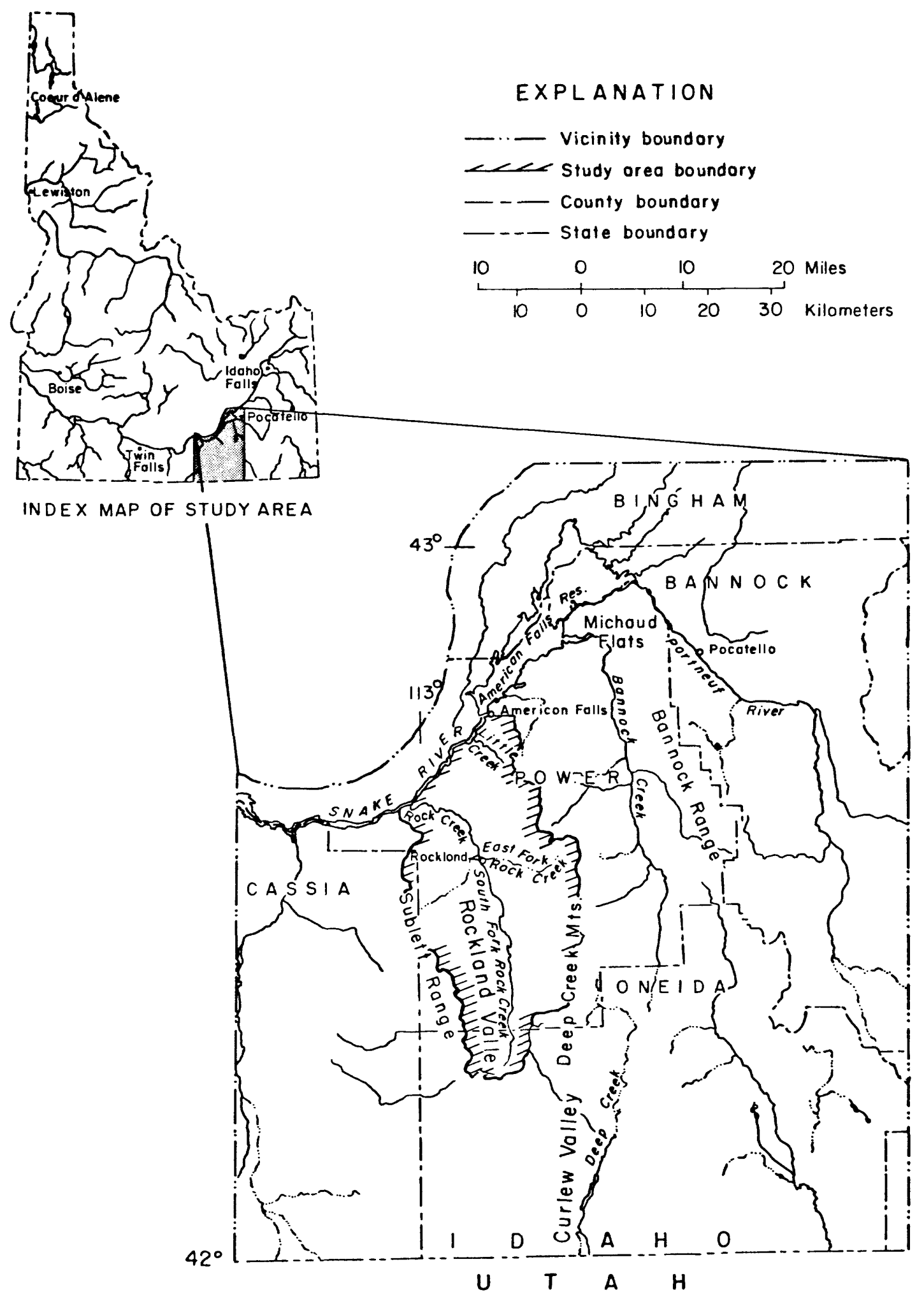

Figure 1.-- Study orea and vicinity. 


\section{Acknowledgments}

Many farmers and landowners in Rockland basin cooperated fully in this study by supplying information on water use and allowing access to their property, supplying construction and hydrologic data pertaining to their wells, and permitting water levels to be measured. Officials and employees of Idaho Power Company supplied power records useful in computing the amount of ground water pumped. To all the above, the authors are grateful.

\section{Well-and Spring-Numbering System}

The well- and spring-numbering system (fig. 2) used by the U.S. Geological Survey in Idaho indicates the location of wells or springs within the official rectangular subdivision of the public lands, with reference to the Boise base line and meridian. The first two segments of the number designate the township and range. The third segment gives the section number, followed by three letters and a numeral, which indicate the $\frac{1}{4}$ section (160-acre tract), the $\frac{1}{4}-\frac{1}{4}$ section (40-acre tract), the $\frac{1}{4}-\frac{1}{4}-\frac{1}{4}$ section (10-acre tract), and the serial number of the well within the tract, respectively. Quarter sections are lettered A, B, C, and D in counterclockwise order from the northeast quarter of each section. Within the quarter sections, 40-acre and 10-acre tracts are lettered in the same manner. Well 8S-30E-23DCC1 is in the SW $\frac{1}{4} \mathrm{SW}^{\frac{1}{4}} \mathrm{SE} \frac{1}{4}$ sec. $23, \mathrm{~T} .8 \mathrm{~S} ., \mathrm{R} .30 \mathrm{E} . .$, and was the first well inventoried in that tract. Springs are designated by the letter "S" following the last numeral; for example, I1S-32E-18AAC1S.

\section{Gaging-Station Numbering system}

Each gaging station and partial-record station in Idaho has been assigned a number in accordance with the permanent numbering system used by the U.S. Geological Survey. Numbers are assigned in a downstream direction along the main stream, and stations on tributaries between main-stream stations are numbered in the order that the tributaries enter the main stream. A similar order is followed on other ranks of tributaries. The complete 8-digit number, such as 13077650, which is used for the station "Rock Creek near American Falls," includes the part number "13," indicating that Rock Creek is in the Snake River basin, plus a 6-digit station number. 


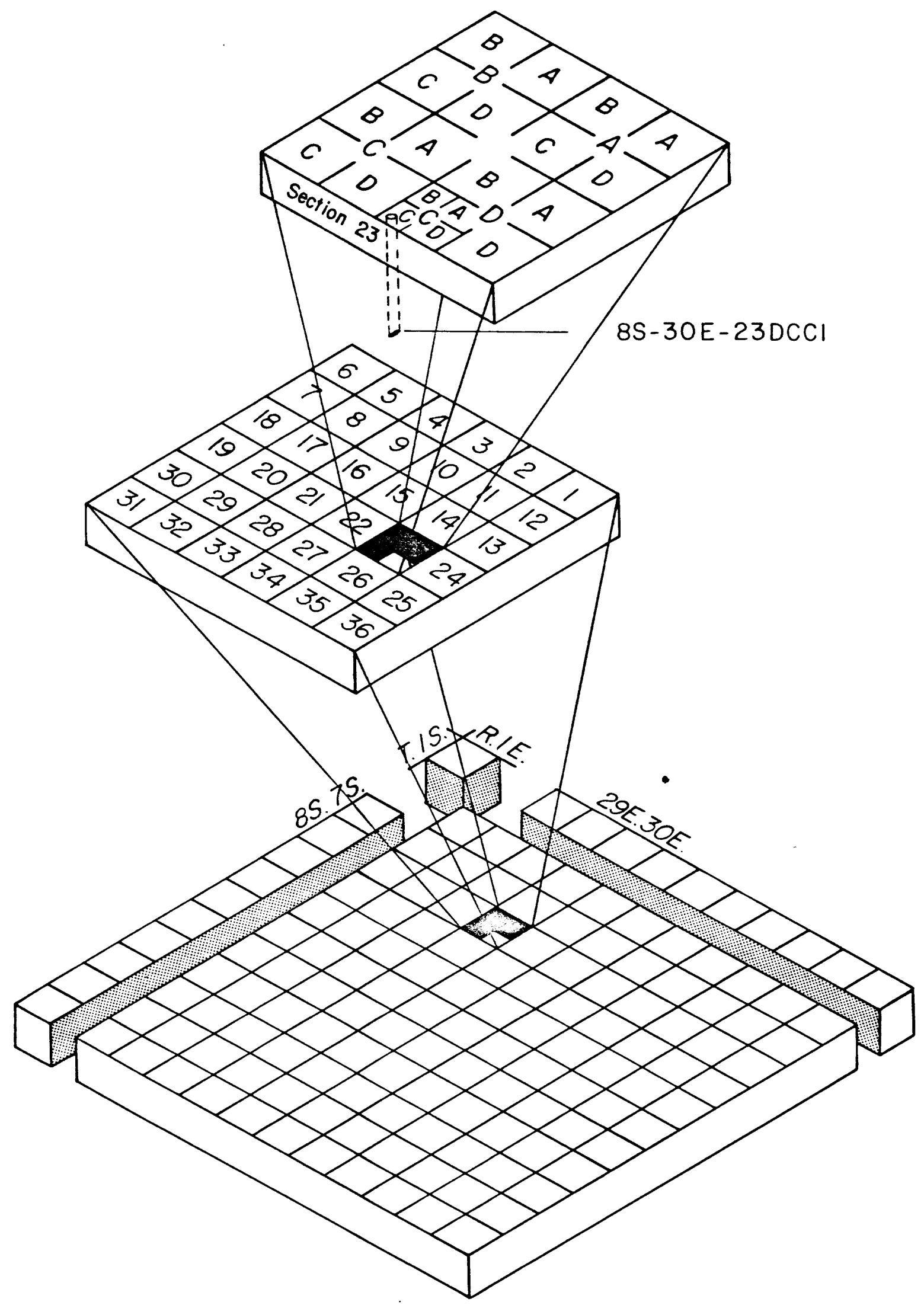

Figure 2.-- Well- and spring-numbering system. 


\section{HYDROLOGIC SETTING \\ Topography and Drainage}

Rockland basin is in the northern part of the Basin and Range physiographic province (Fenneman, 1931). The basin is roughly elliptical; the long axis is oriented in an approximate north-south direction. Land-surface altitudes range from 4,200 ft NGVD (National Geodetic Vertical Datum of 1929), where Rock Creek joins the Snake River, to $8,700 \mathrm{ft}$ NGVD at Deep Creek Peak in the Deep Creek Mountains, which form the eastern border of the basin. The western border is formed by the sublett Range, which rises to an altitude of 7,500 ft at Hartley Peak. The southern border is the divide (altitude $5,690 \mathrm{ft}$ ) between Rockland basin and Curlew Valley and is formed by a relatively narrow swale that lies between the Deep Creek Mountains and Sublett Range. The northern border is formed by a subtle divide between the drainages of Rock Creek and Little Creek.

The central part of the basin is a valley about $30 \mathrm{mi}$ long and 10-15 $\mathrm{mi}$ wide and has an average altitude of about 5,000 ft. On the eastern and western sides of the valley, broad piedmonts extend from the mountain fronts to the valley floor, which is essentially composed of the flood plains of Rock and South Fork Rock Creeks. The northern part of the valley is characterized by rolling foothills that merge with Michaud Flats, a broad, alluvial plain 3-4 mi wide adjacent to the snake River.

Drainage in Rockland basin is provided by Rock Creek, which flows generally in a northward direction to the snake River. Although Rock Creek is intermittent in much of its upper reaches, it is perennial in its lower reaches, where it is sustained by ground-water discharge.

With the exception of East Fork Rock and Spring Creeks, tributary streams to Rock Creek are intermittent and flow only during periods of heavy rainfall. Perennial flow in East Fork Rock and Spring Creeks is sustained by springs.

\section{Climate}

Climatic conditions vary in the basin from semiarid on the valley floor to subhumid in the bordering mountains because of the appreciable differences in topographic relief. Summers are generally warm and dry and winters are cold and wet. No weather stations are located in the basin; however, annual average temperatures recorded at the National Weather Service station at American Falls (altitude 4,318 ft), about $8 \mathrm{mi}$ north of the basin, range from $23.9^{\circ} \mathrm{F}$ 
$\left(-4.5^{\circ} \mathrm{C}\right)$ in January to $70.7^{\circ} \mathrm{F}\left(21.5^{\circ} \mathrm{C}\right)$ in July. Annual average precipitation at American Falls is 10.4 in. for 63 years of record.

As part of this study, three precipitation-storage cans were installed at high-altitude locations (fig. 3 ) in the basin. Using data obtained from these stations and nearby National weather Service stations and altitude-precipitation relations of nearby basins, an estimated precipitationaltitude relation curve (fig. 4) was derived for Rockland basin.

The straight-line slope of the curve is idealistic, because effects of rain shadows and any unique weather patterns common to subareas of the basin are not accounted for in the calculations. However, the curve can be used to draw a map of the generalized distribution of precipitation (fig. 3). Average annual precipitation ranges from 11 in. near the snake River in the northern part of the basin to more than 35 in. near Bannock Peak in the Deep Creek Mountains (fig. 3). The climatic data indicate that precipitation increases rapidly with altitude and is greatest on west-facing slopes. The eastern slopes of the Sublett Range are in a rain shadow, whereas the western slopes of the Deep Creek Mountains are more directly exposed to moisture-laden air masses. On the basis of a mean altitude of $5,700 \mathrm{ft}$, mean annual precipitation for Rockland basin is 17.3 in. (fig. 4 ).

Yearly variation in precipitation was compared for five stations by plotting the cumulative departure of yearly precipitation from the long-term mean for the period 1950-78 (fig. 5). The graph trends can be used to infer a near"normal" precipitation condition in the late 1970's (the time of this study). The Conda (precipitation station) data were included to compare long-term trends of precipitation differences at a distant location and at a higher altitude. Conda is about $65 \mathrm{mi}$ east of the study area at an altitude of $6,200 \mathrm{ft}$. Precipitation trends seem to be compatible at all sites used, indicating that the regional precipitation pattern is similar.

\section{Geology}

For purposes of this study, geologic formations in Rockland basin are divided into (1) undifferentiated pre-Tertiary sedimentary rocks, (2) Tertiary sedimentary rocks, (3) Quaternary-Tertiary volcanic rocks, (4) Pleistocene gravel, (5) Pleistocene windblown (loess) deposits, and (6) Holocene alluvium. Areal distribution of these units is shown in figure 6 . 


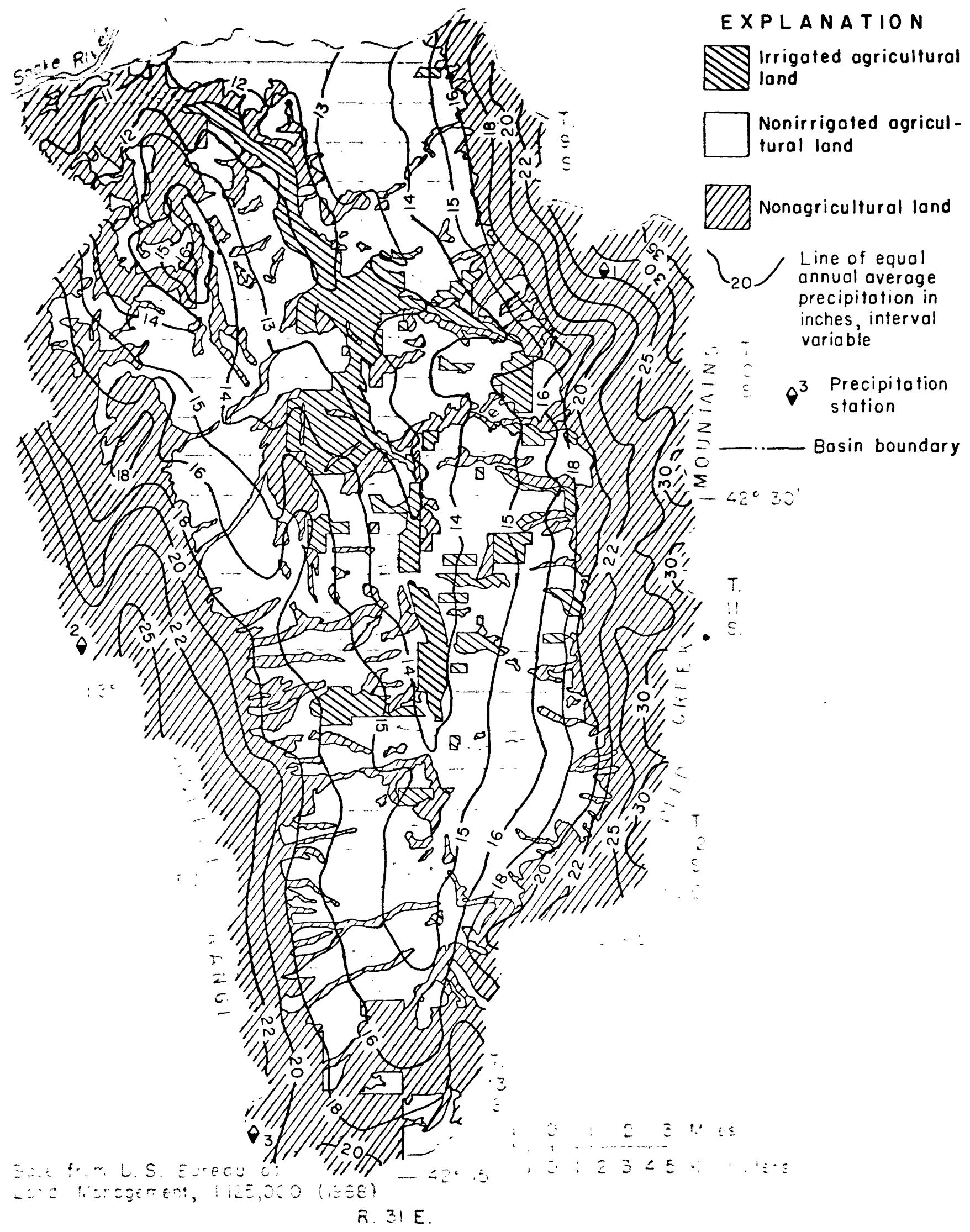

Figure 3.-- Distribution of 
Precipitation data for Rockland basin

(From three U.S. Geological Survey precipitation stations)

Precipitation, in inches

Period of data collection
East Fork (1) Houtz Canyon (2) South Fork (3)

August 24, 1978-

January 18, 1979

11.1

8.8

6.4

January $19,1979-$

November 15, 1979

19.2

19.0

13.8

November $16,1979-$

June 4, 1980

31.4

26.9

16.3 


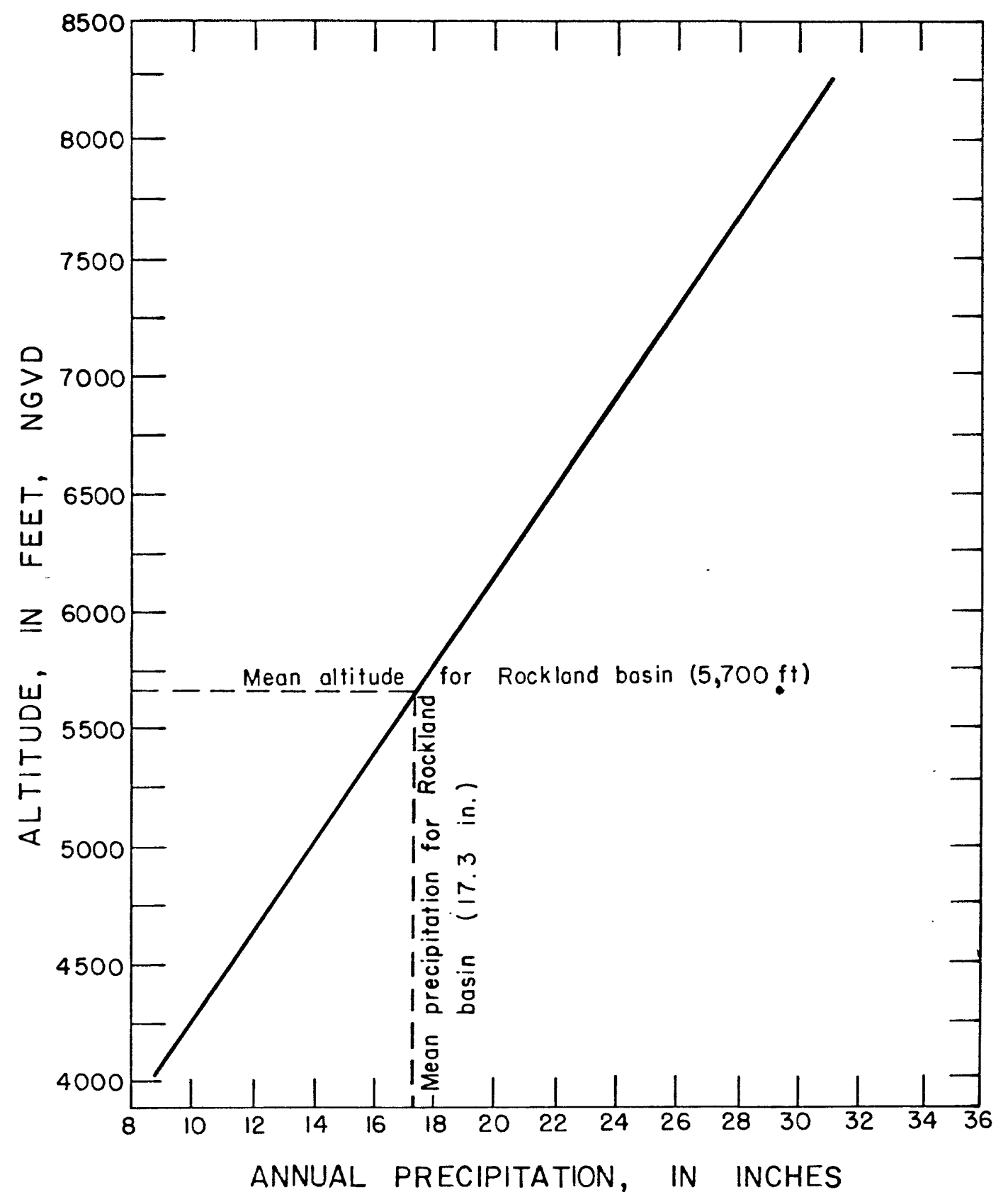

Figure 4. -- Estimated precipitation-altitude relation. 


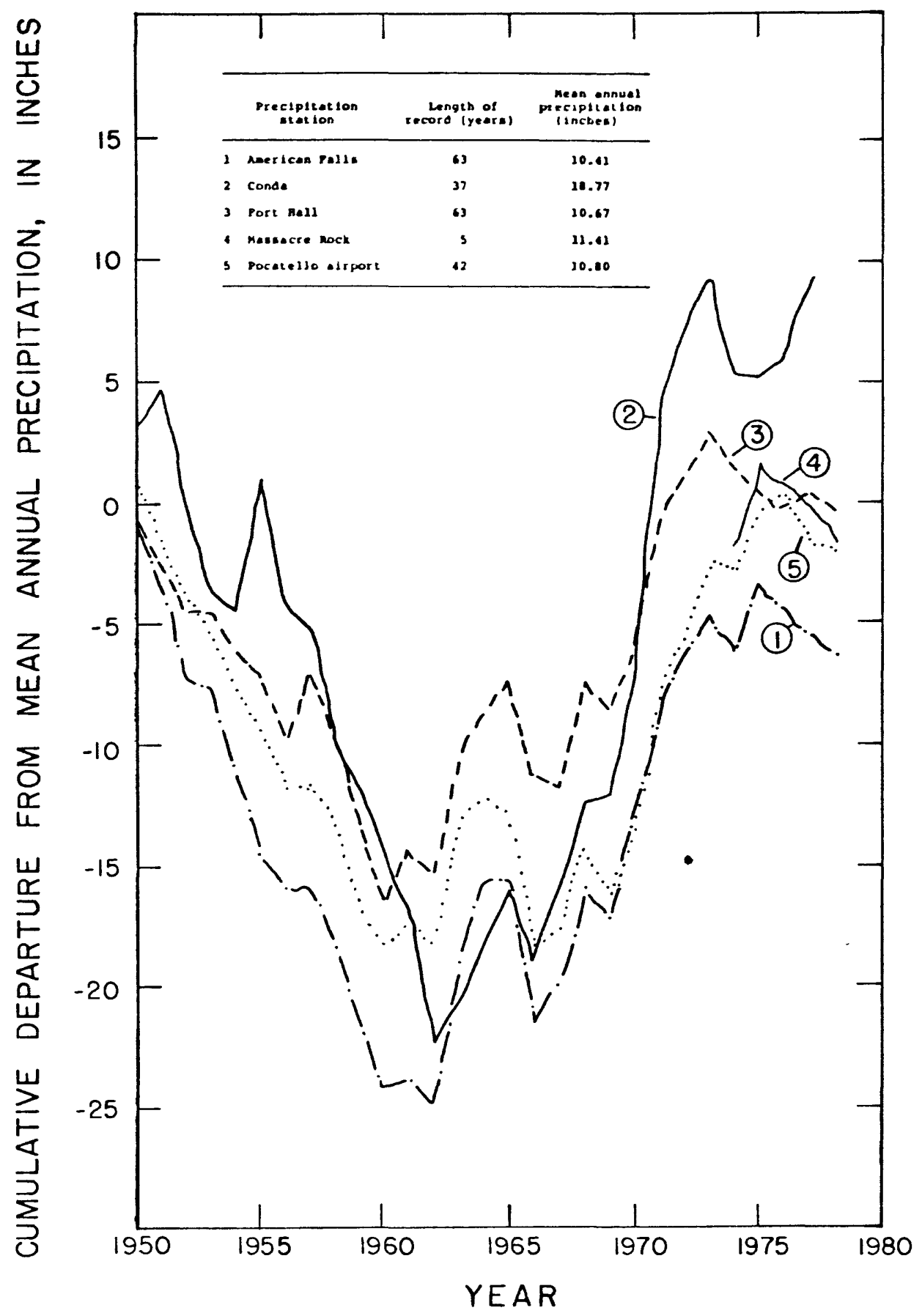

Figure 5.-- Cumulative departure of yearly precipitation for the period 1950-79 from the long-term mean. (Data from National Weather Service) 
CORRELATION OF MAP UNITS

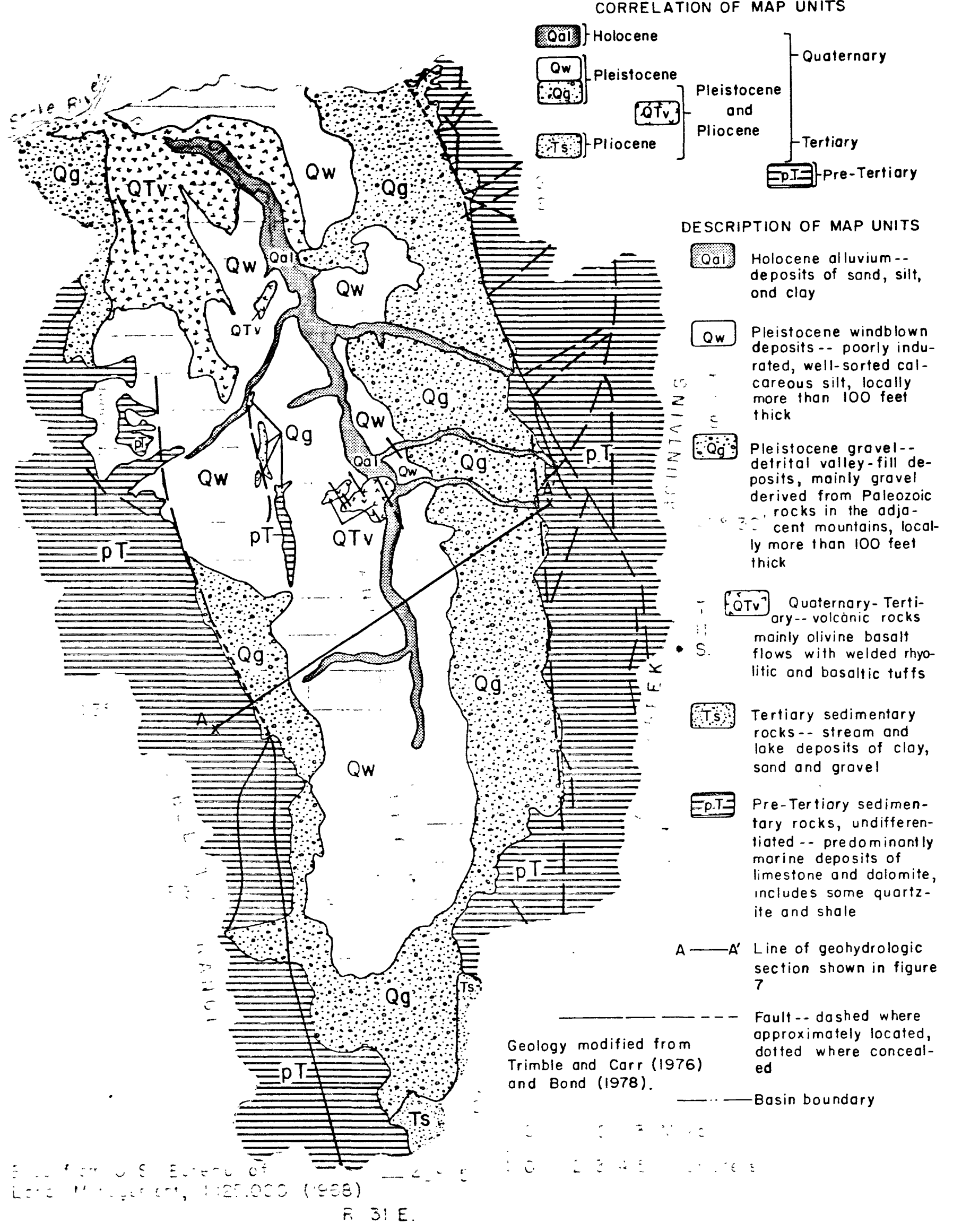

Figure 6.-- Generalized geology. 
Pre-Tertiary sedimentary rocks, consisting chiefly of marine deposits of 1 imestone and dolomite, comprise the mountainous parts of the basin and are thought to underlie the valley fill. Rocks in this unit are intensely folded and faulted. Structural details are largely unknown, but the unit is thought to be comprised of individual fault blocks that are separately tilted northeastward (fig. 7). The thickness of the unit may exceed 25,000 ft (Trimble and Carr, 1976).

Tertiary sedimentary rocks, derived mainly from detrital material from the surrounding mountains, constitute the lowermost unit of the valley fill. This unit consists primarily of gravel, sand, and silt, which locally include some rhyolitic material and interbedded volcanic tuff. The Tertiary sedimentary rocks crop out only in the southern part of the basin (fig. 6), but they are the principal rocks underlying the upper parts of the valley fill (fig. 7). The thickness of the unit is unknown.

Quaternary-Tertiary volcanic rocks are composed primarily of olivine basalt flows. These rocks crop out in the northern part of the basin where the flows served as dams that formed a series of ancient lakes, in which deposits of gravel, sand, silt, and clay accumulated. Thicknesses of individual basalt flows are highly variable but are generally less than $100 \mathrm{ft}$.

Pleistocene gravel, derived mainly from detrital material from the nearby mountains, form broad piedmonts along the mountain fronts on both sides of the valley. The thickness of the gravel is highly variable but locally may exceed $100 \mathrm{ft}$.

Pleistocene windblown deposits, consisting chiefly of calcareous silt, mantle much of the valley. These deposits are generally less than $100 \mathrm{ft}$ thick.

Holocene alluvium, composed chiefly of sand, silt, and clay, is exposed in the streambeds of the valley. These deposits are of variable thickness and generally are restricted to narrow bands along the stream courses. The maximum thickness of the unit is probably less than 50 ft.

WATER RESOURCES

Water Yield

The water supply of the basin is the total quantity of water available from all sources. The ultimate and total source of the supply comes from precipitation on the basin. 


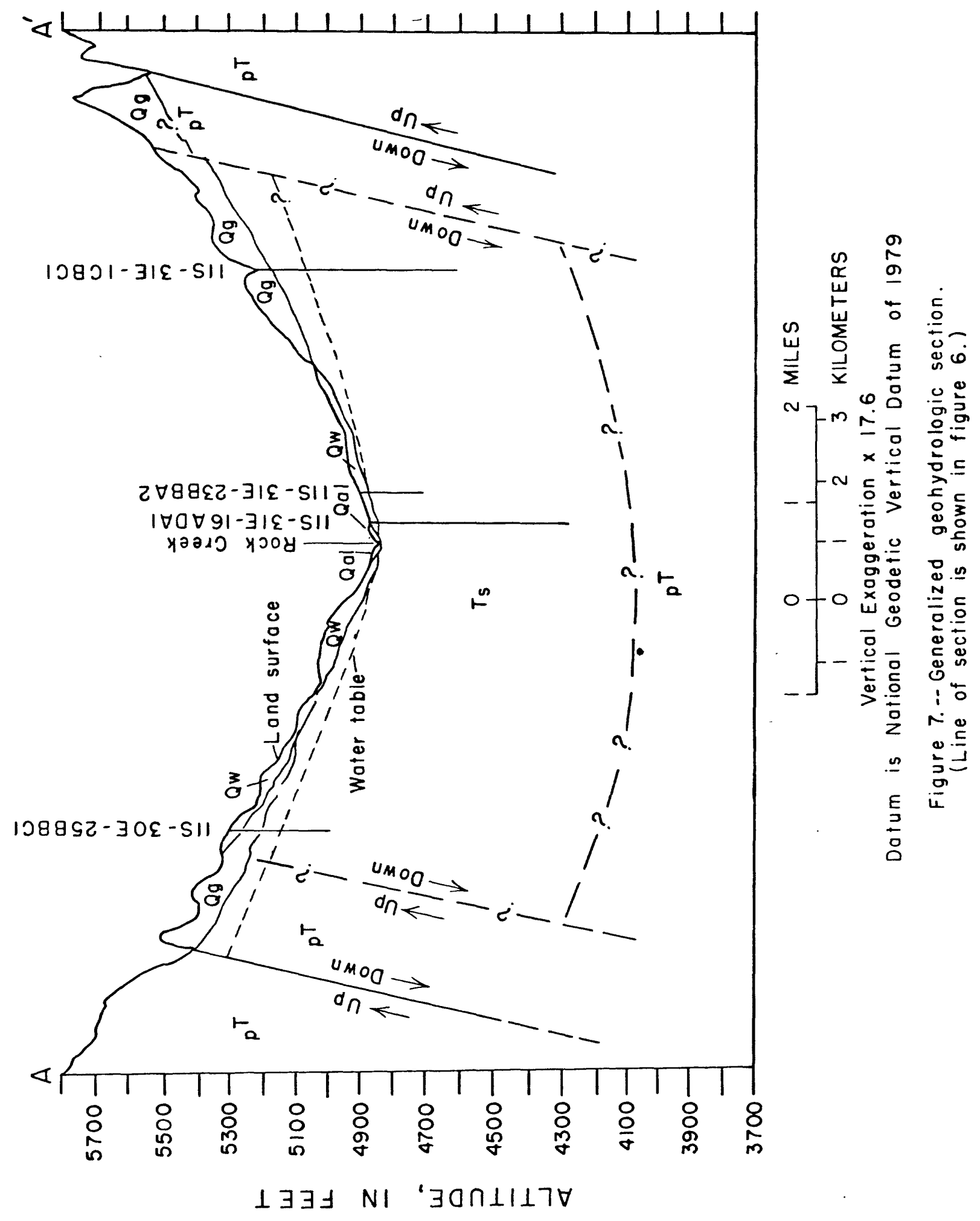


Although precipitation ranges from 11 to 35 in./yr on the basin, the basin average was calculated to be about 17.3 in./yr, or a total of 295,000 acre-ft. It is assumed that any difference in interbasin underflow is negligible and that the ground-water divide bordering the basin lies directly beneath the surface-water divide. No water is exported from or imported to the basin. Quantities of the water available are consumed by evaporation, transpiration from natural vegetation and crops, and domestic and other water uses. After these water demands are met, any remaining water leaves the basin as surface flow and as underflow to the snake River.

The usable part of the basin's water supply, or the water yield, is defined as the volume of precipitation minus the volume of water lost to evaporation and transpiration by natural vegetation. Subtracting the water consumptively used by crops, principally on irrigated fields, and by other man-related uses, from the water yield gives the quantity of water leaving the basin as combined surface flow and underflow.

Four methods were used to estimate water yield. They are: (1) a method proposed by Langbein (Nace and others 1961); (2) a method based on the difference between monthly precipitation and monthly potential ET (evapotranspiration) summed over a seasonal basis, using a modified procedure by Walker, Dutcher, Decker, and Dyer (1970); (3) a method using estimated soil-moisture requirement at the time of snowmelt subtracted from the amount of precipitation accumulated as snow from November to April; and (4) a method suggested by Mundorff, Crosthwaite, and Kilburn (1964), which uses a curve relating water yield to average annual precipitation.

A comparison of water-yield estimates made using the four methods is shown in figure 8. It is significant that an average altitude of 5,700 ft for Rockland basin corresponds with a water yield (on the basis of the average of methods 1-3) of 5.0 in., or 85,000 acre-ft/yr, or similar to the amount obtained by using the relation of Mundorff, Crosthwaite, and Kilburn (1964, method 4). Also of interest is the merging of water yields of 10.4 in. near the $7,000-\mathrm{ft}$ altitude line shown in figure 8 . The pre-Tertiary sedimentary rocks, which are exposed at this altitude, are thought to supply the majority of water to the basin.

All yield values are based on an estimated precipitation distribution. Because precipitation in Rockland basin can vary greatly at any one place during any particu- 


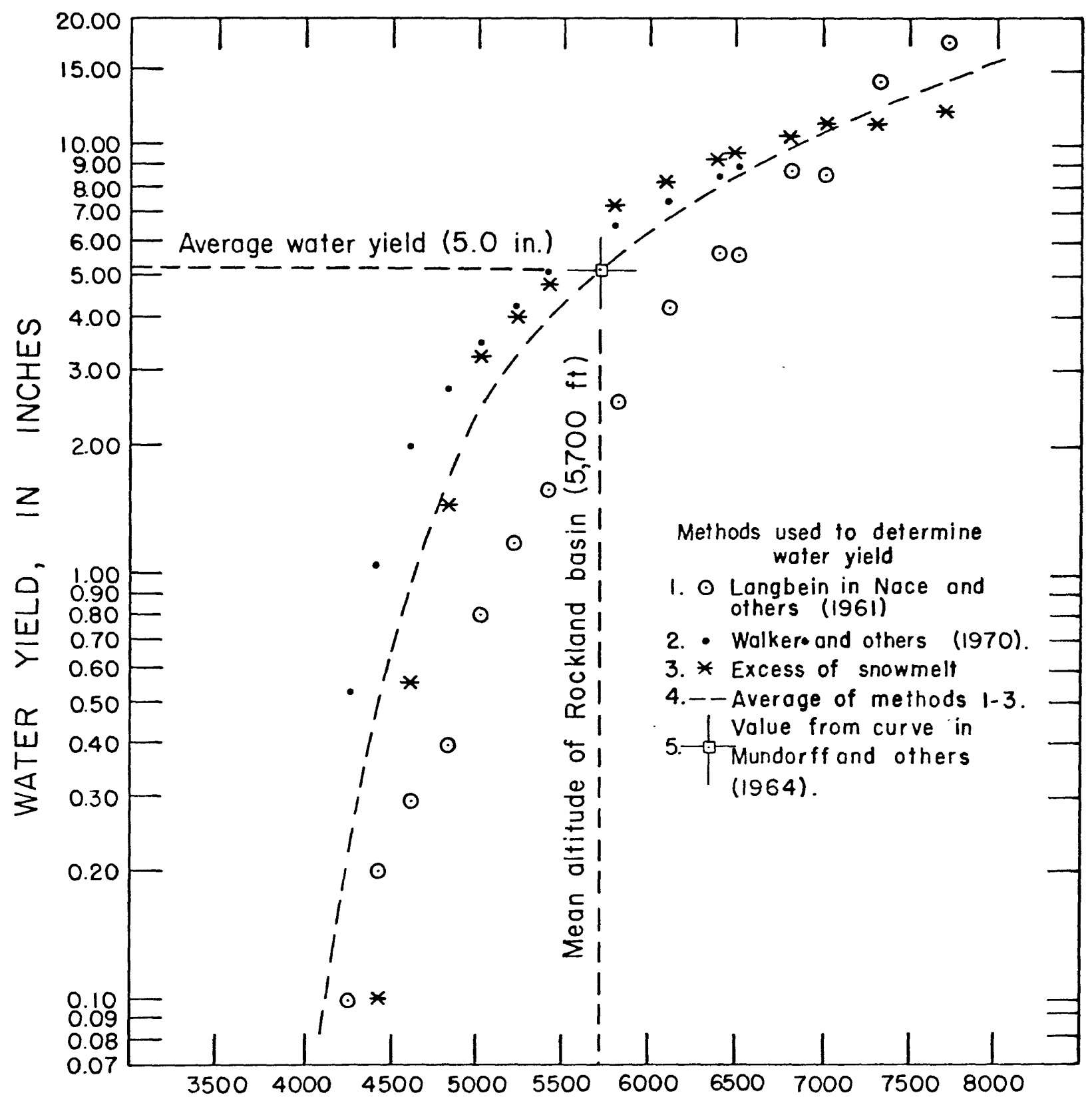

ALTITUDE, IN FEET NGVD

Figure 8. - Estimated woter yield. 
lar period, any estimate of precipitation should be considered tentative. Records of rainfall from December 1979 to June 1980 were not included in the precipitation analysis of long-term trends because recurrence frequency of such rainfall intensities is in excess of long-term averages.

The estimation of 5.0 in. of water yield used in the remainder of this report is considered to be a reasonable value for water yield. This estimate agrees with estimated water yields for most adjacent basins (table 1 ).

\section{Surface Water}

Collection of streamflow data in Rockland basin began in 1955 with establishment of the gaging station Rock Creek near Rockland (13077500). Since 1955, various gages were operated intermittently to record daily flows. From 1955 to 1960, a gaging station was operated on the East Fork Rock Creek near Rockland (13077600). From 1960 to 1964, the station was relocated about $2 \mathrm{mi}$ upstream. The station was discontinued in 1964.

During this study, the upper gage on East Fork Rock Creek (13077600) was reactivated to provide continuous flow record, and a continuous-recording gage was installed on Rock Creek near American Falls (13077650). In addition, discharge measurements were made monthly at 12 miscellaneous sites to aid in defining flow distribution within the basin. peak discharge was estimated at five crest-stage sites during periods of high flow during 1978-80. Additional flow measurements were made during high runoff in January 1980 . Locations of the measuring sites are shown in figure 9 .

Discharge measurements made prior to 1967 are summarized by Decker and others (1970). Subsequent miscellaneous measurements made in the basin are published in annual reports by the U.S. Geological Survey.

\section{Annual Discharge}

Total surface-water discharge from the basin is measured at the gaging station Rock Creek near American Falls (13077650, fig. 9). Annual discharge for the 1979 and 1980 water years, which include the period of this study, was 19,800 and 28,900 acre-ft, respectively. The major contributor of flow to Rock Creek is East Fork Rock Creek (13077600), with a mean annual discharge of 10,500 acre-ft during 1961-64. Mean annual discharge was 12,900 acre-ft for the 1979 water year and 13,700 acre-ft for the 1980 water year. 
Table 1.--Estimated water yields in southeastern Idaho basins

\begin{tabular}{|c|c|c|c|c|}
\hline River basin & $\begin{array}{c}\text { Drainage } \\
\text { area } \\
\left(m i^{2}\right)\end{array}$ & $\begin{array}{l}\text { Precipitation } \\
\quad(\text { in } / / y r)\end{array}$ & $\begin{array}{l}\text { Evapotrans- } \\
\text { piration } \\
\text { (in./yr) }\end{array}$ & $\begin{array}{l}\text { water } \\
\text { yield } \\
\text { (in./yr) }\end{array}$ \\
\hline Maladi & 485 & 18.5 & 14.5 & 4.0 \\
\hline Raft River ${ }^{2}$ & 1,560 & 15.5 & 13.3 & 2.2 \\
\hline $\begin{array}{c}\text { Raft River }{ }^{2} \\
\text { (Valley) }\end{array}$ & 716 & 13.7 & 12.3 & 1.4 \\
\hline Little $\operatorname{Los}^{3}$ & 900 & 22.6 & 17.4 & 5.2 \\
\hline Portneuf ${ }^{4}$ & 1,160 & 19.6 & 14.1 & 5.5 \\
\hline Big Lost 5 & 1,400 & 20.2 & 13.9 & 6.3 \\
\hline Bannock ${ }^{6}$ & 413 & 18.0 & 12.0 & 6.0 \\
\hline Rock 1 and 7 & 320 & 17.3 & 12.3 & 5.0 \\
\hline
\end{tabular}

${ }^{1}$ Pluhowski (1970).

${ }^{2}$ Mundorff, Crosthwaite, and Kilburn (1964).

${ }^{3} \mathrm{Clebsch}$, Waite, and Decker (1974).

${ }^{4}$ Norvitch and Larson (1970).

${ }^{5}$ Crosthwaite, Thomas, and Dyer (1970).

${ }^{6} \mathrm{Balmer}$ and Noble (1979).

${ }^{7}$ This study. 


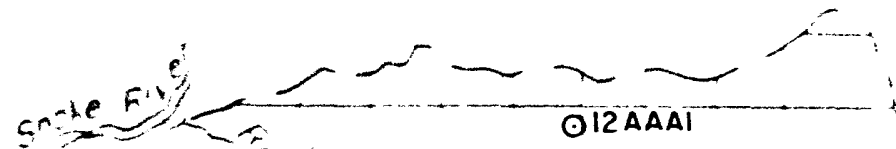

EXPLANATION

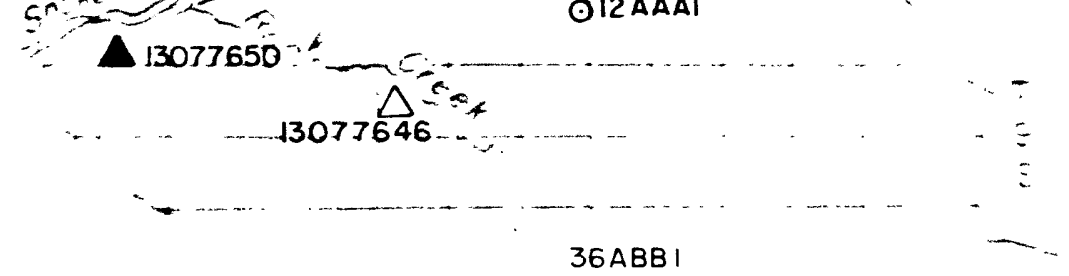
A 13077650 Continuous record station $8^{13077500}$ Discontinued station

$\triangle 13077620$ Miscellaneous meosurement site $\triangle 13077340$ Peak-flow measurement site

OZIADDI Well

Q I8ACCIS Spring

$13077638 \triangle \triangle^{\circ} \triangle^{13077632}$

$\theta_{1}$ Precipitation storage can

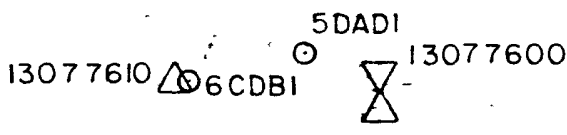

$\theta_{1}$

13077540

13077600

…

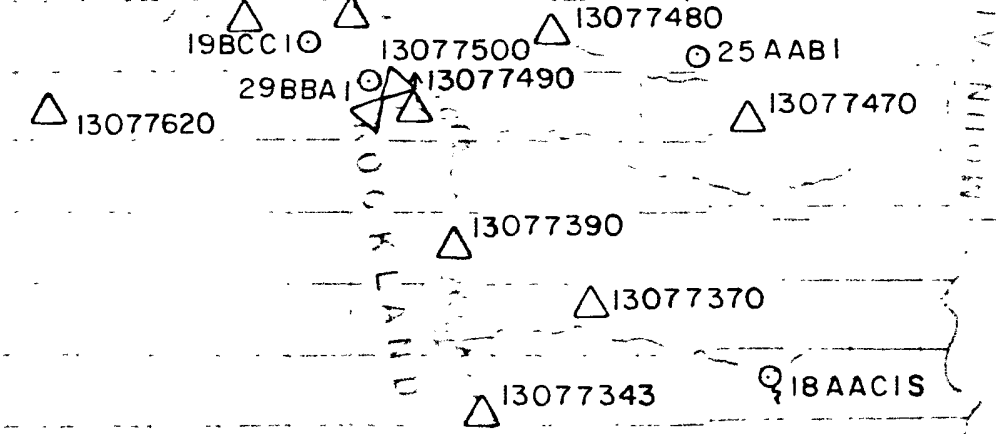

$\Delta_{2} \ldots \triangle_{13077340}{ }^{21 A D D I}$

$\Delta^{13077300}$

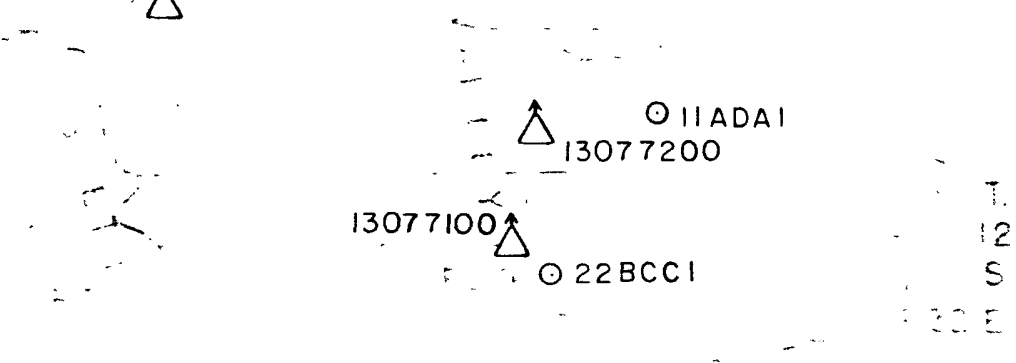

$1.2=-5$

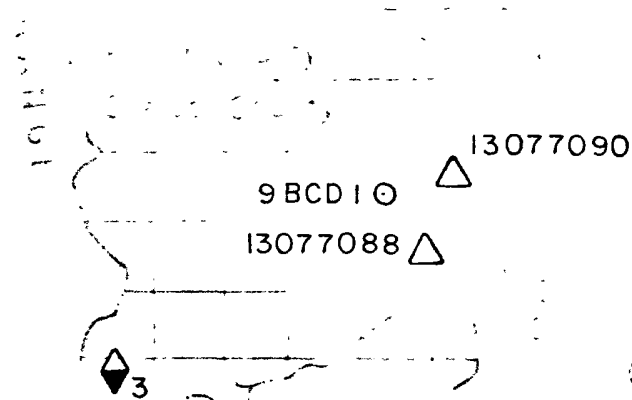

$=E-E D E$

$\div$ ?

$-42^{\circ}$

$\therefore \Xi E$

Figure 9. -- Locations of meosuring sites. 
During 1979, monthly flow measurements were made at tributary sites shown in figure 9, and hydrographs were prepared to determine annual distribution of flow. Perennial discharge at some of the sites is sustained by springs; however, at other sites, flow is seasonal.

Discharge records (1955-58) for Rock Creek near Rockland (13077500) were correlated with those for Bannock Creek near Pocatello (drainage area of $230 \mathrm{mi}^{2}$ ) to estimate periods of no flow, owing to upstream irrigation diversions. The average annual discharge (1956-60), after upstream diversion of about 1,050 acre-ft during the irrigation season, was 3,780 acre-ft at Rock Creek near Rockland (13077500). Unfortunately, the record at Bannock Creek was too short to make an estimate of long-term average annual discharge for Rock Creek. No acceptable correlation could be made with nearby basin streams, nor could correlation of precipitation records with discharges of Rock Creek be done satisfactorily.

On the basis of the annual discharge from tributaries (1979), Rock Creek (1955-60, 1979), and East Fork Rock Creek (1955-64, 1979), the estimated annual average surface-water outflow from Rockland basin is 16,500 acre-ft. In comparison, Mundorff, Crosthwaite, and Kilburn (1964) estimated that the annual surface-water discharge from Rockland basin averaged about 13,000 acre-ft.

\section{Daily Discharge}

Daily-discharge records provide detailed information about the flow characteristics of a stream. When daily records are available for many years, duration hydrographs and flow-duration curves can be developed. A flow-duration curve shows the percentage of time that a specific daily discharge has been equaled or exceeded for the period examined. The daily hydrographs of continuous-record stations for water year 1979 on Rock Creek (13077650) and East Fork Rock Creek (13077600) are shown in figure 10 . They show a wide variability of flows in Rock Creek and unusually stable flows in East Fork Rock Creek. Duration curves for selected periods of record are shown in figure 11. The flow-duration curve of East Fork Rock Creek shows that, during the period of record, $24 \mathrm{ft} / \mathrm{s}$ was equaled or exceeded about 1 percent of the time and $11 \mathrm{ft}^{3} / \mathrm{s}$ nearly 100 percent of the time; whereas flow at two sites about 14 $\mathrm{mi}$ apart on Rock Creek was greater than $1 \mathrm{ft}^{3} / \mathrm{s}$ about 48 and 92 percent of the time. The flat slope of the East Fork Rock Creek flow-duration curve indicates uniform sustained perennial flow conditions in the East Fork caused by springs 


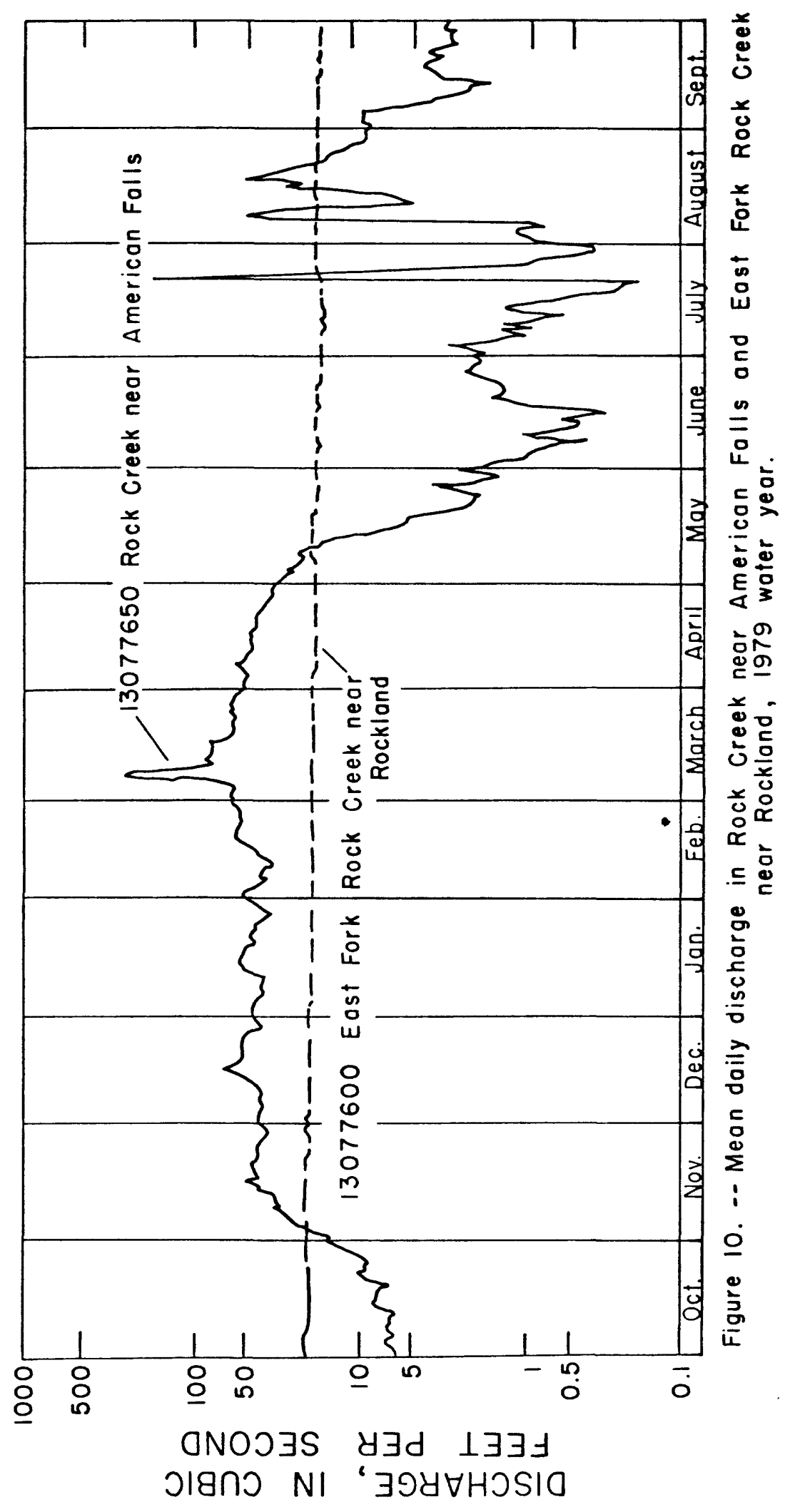




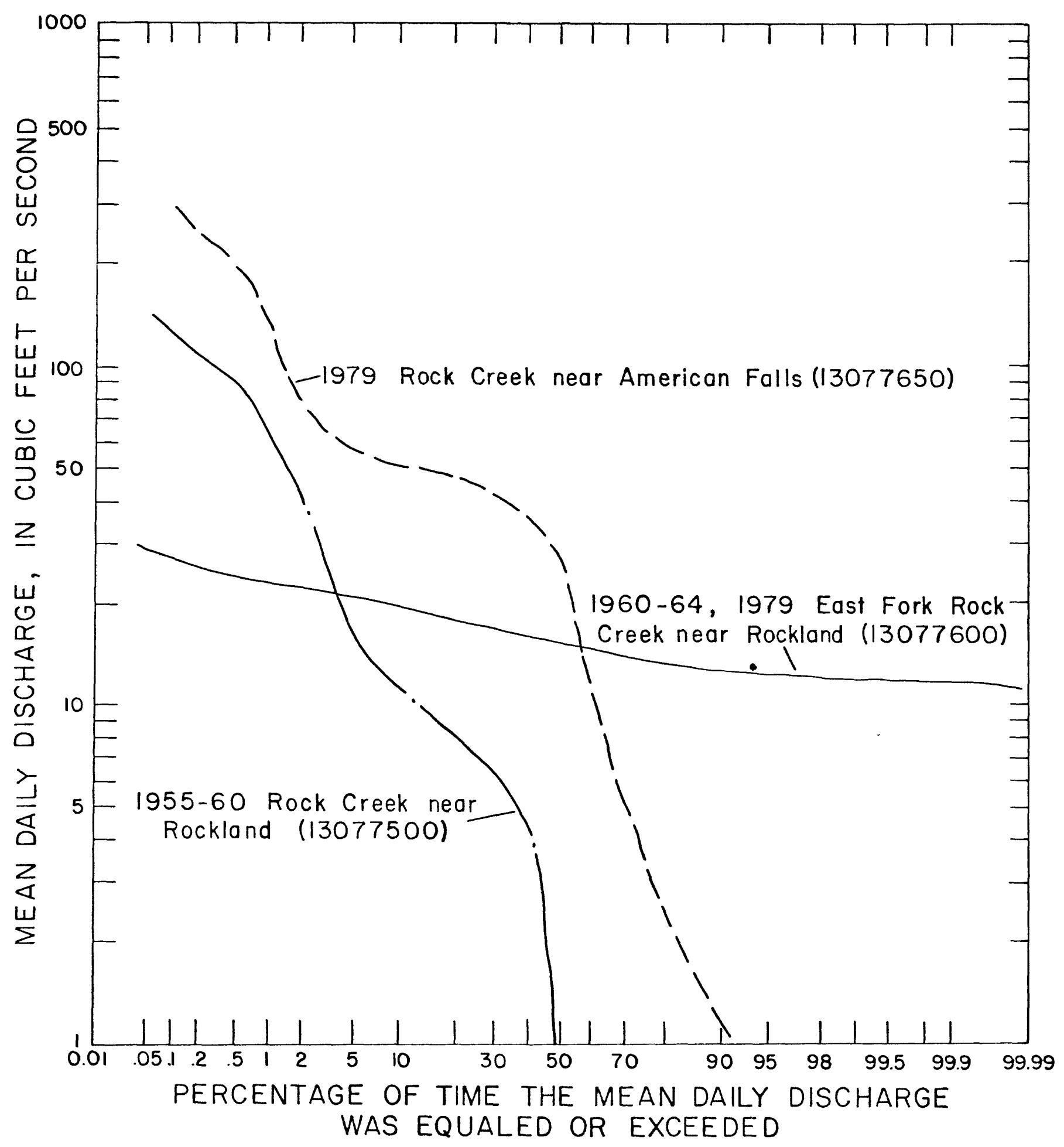

Figure 11.-- Flow-duration curves for Rock Creek and Eost Fork Rock Creek for periods of record. 
in the upper reaches of the creek. The steep slopes of the Rock creek curves show a flashiness in surface flows, which indicates little ground-water contribution above the gaging-station sites.

\section{Peak Runoff}

The magnitude and distribution of floods in Rockland basin are affected by climate, basin physiography, and geology. Warm temperatures (causing snowmelt), precipitation on frozen ground, and minimal ET losses during late winter and early spring maximize potential flooding. Occasionally, localized thunderstorms produce high-magnitude floods during the summer in some of the tributary basins.

Peak discharges from streams measured since data collection began in Rockland basin are shown in table 2 . Also shown in the table are peak discharges estimated from indirect measurements made in July 1979 and January 1980, shortly after substantial flooding occurred in the basin.

Generally, long-term annual peak discharges are evaluated statistically to determine magnitude and recurrence intervals of floods, but peak-flow records within Rockland basin are too short for an accurate appraisal. Therefore, recurrence interval and discharge magnitude of floods were estimated (table 3) using regression equations recently developed for southern Idaho by Kjelstrom and Moffatt (1981). These equations were determined for the mean and standard deviation of annual maximum discharges that result from the combined effects of snowmelt and rainfall, conditions similar to those in Rockland basin. On the basis of comparison of flood peaks (table 2) at South Fork Rock Creek (13077200), Sand Hollow Creek (13077490), and Rock Creek near American Falls (13077650) with data in table 3, the January 1980 peak flows occurred at a 50-year recurrence interval; that is, these flow magnitudes would be equaled or exceeded on the average of once every 50 years.

\section{$\frac{\text { Ground water }}{\text { Occurrence }}$}

Ground water occurs in most of the geologic units mapped in Rockland basin (fig. 6). Major aquifers in the basin occur in Quaternary-Tertiary volcanic rocks and in Tertiary sedimentary rocks. Basalt and sedimentary rocks interbedded in the Quaternary-Tertiary volcanic rocks are the principal aquifers in the northern part of the basin. Ground water is generally under water-table conditions and 
Table 2.--Measured peak discharges at selected sites

\begin{tabular}{|c|c|c|c|c|}
\hline $\begin{array}{l}\text { Site } \\
\text { No. }\end{array}$ & $\begin{array}{l}\text { Site } \\
\text { name }\end{array}$ & $\begin{array}{c}\text { Drainage } \\
\text { area } \\
\left(\mathrm{mi}^{2}\right)\end{array}$ & $\begin{array}{c}\text { Date } \\
\text { measured }\end{array}$ & $\begin{array}{c}\text { Discharge } \\
\left(\mathrm{ft} \mathrm{t}^{3} / \mathrm{s}\right)\end{array}$ \\
\hline 13077100 & Trail Creek & 11 & $\begin{array}{l}9-9-61 \\
1-13-80\end{array}$ & $\begin{array}{l}487 \\
140\end{array}$ \\
\hline 13077200 & $\begin{array}{l}\text { South Fork } \\
\text { Rock Creek }\end{array}$ & 96 & $\begin{array}{l}2-11-62 \\
2-1-63 \\
1-13-80\end{array}$ & $\begin{array}{l}1,770 \\
1,470 \\
1,190\end{array}$ \\
\hline 13077340 & $\begin{array}{l}\text { Hartley Canyon } \\
\text { Creek }\end{array}$ & 11 & $1-13-80$ & 140 \\
\hline 13077400 & $\begin{array}{l}\text { South Fork } \\
\text { Rock Creek }\end{array}$ & 156 & $\begin{array}{r}2-1-63 \\
12-23-64\end{array}$ & $\begin{array}{l}5,100 \\
3,750\end{array}$ \\
\hline 13077490 & $\begin{array}{l}\text { Sand Hollow } \\
\text { Creek }\end{array}$ & 12.3 & $1-13-80$ & 1440 \\
\hline 13077540 & Warm Springs & 22 & $7-21-79$ & 1390 \\
\hline 13077550 & Rock Creek & 216 & $2-11-62$ & 2,120 \\
\hline 13077600 & $\begin{array}{l}\text { East Fork } \\
\text { Rock Creek }\end{array}$ & 13.7 & $\begin{array}{l}9-18-61 \\
3-27-62 \\
2-1-63 \\
6-12-64\end{array}$ & $\begin{array}{l}23 \\
26 \\
39 \\
43\end{array}$ \\
\hline 13077630 & $\begin{array}{l}\text { Spring Creek } \\
\text { tributary }\end{array}$ & 6.8 & $8-18-61$ & 152 \\
\hline 13077640 & $\begin{array}{l}\text { Rocky Hollow } \\
\text { tributary }\end{array}$ & 2.3 & $5-30-63$ & 498 \\
\hline 13077650 & Rock Creek & 320 & $\begin{array}{r}2-11-62 \\
12-23-64 \\
7-21-79 \\
1-13-80\end{array}$ & $\begin{array}{l}3,300 \\
7,950 \\
1,480 \\
3,990\end{array}$ \\
\hline
\end{tabular}

${ }_{1}$ Estimated from indirect measurements. 
Table 3.--Estimated peak discharges (Q) at selected stream sites ${ }^{1}$ [Discharge in cubic feet per second. $Q_{5}$ designates a recurrence interval of 5 years]

Site No.

(location

shown in

fig. 9)

\section{Recurrence interval}

$Q_{25}$

$Q_{50}$
$Q_{1.01} \quad Q_{1.02}$

3.0

9.2

45

92

136

209

278

588

318

247

929

593

27

43

242

356

162

108

791

1,210

42

37

7.6

21

90

167

233

312

423

83

115

153

206

148

209

134

90

1,270

1,870

2,870

3,810

3,860

127

619

1,300

1,910

2,910

459

43

132

637
$Q_{100}$

13077646

13077650

${ }^{1}$ Based on regression equations developed by 
occurs mainly in fractures, joints, and breccia zones within individual lava flows and in sand and gravel lenses that are interbedded within the flows. Sand and gravel sequences in the Tertiary sedimentary rocks are the principal aquifers in the central and southern parts of the basin. Ground water in the Tertiary sedimentary rocks generally is also under water-table conditions; however, artesian conditions may exist locally.

Holocene alluvium along the major streambeds on the valley floor is locally an important aquifer. Ground water here is under water-table conditions and occurs mainly in sand lenses.

Pleistocene gravel and windblown deposits are thin and are generally above the water table (fig. 7). Small quantities of water are available where the deposits are below the water table. Of hydrologic significance is the occurrence of springs that issue from the contact between the gravel and the underlying Tertiary sedimentary rocks. The presence of these springs at the geologic contact indicates that precipitation readily percolates through the gravel but is retarded by the underlying rocks.

The hydrologic significance of the pre-Tertiary sedimentary rocks as aquifers in Rockland basin is largely unknown. However, owing to their faulted and highly jointed condition and the absence of well-defined stream channels on their surface, the rocks may readily absorb and transmit water to the ground-water system.

\section{Source and Movement}

The source of recharge to aquifers in Rockland basin is precipitation. Part of the precipitation runs off overland, part is consumed by ET, and the remainder percolates downward and recharges the ground-water system. The greatest part of the recharge originates in the mountains that border the basin (fig. 3). Recharge also occurs as percolation losses from stream channels, irrigation canals, irrigated fields, and from precipitation on the valley floor.

Recharge to the aquifers also may occur as interbasin flow from the eastern side of the Deep Creek Mountains (Balmer and Noble, 1979). Recharge also may occur as upward leakage from deep thermal aquifers below the sublett Range, located about $5 \mathrm{mi}$ west of the study area (Nichols, 1979). Present data are insufficient, however, to quantify the amount of recharge from these two possible sources. 
From a preceding section on water yield, it is estimated that an annual average of 10.4 in. of net precipitation recharges the mountain areas at altitudes of $7,000 \mathrm{ft}$, whereas less than $0.2-0.5$ in. recharges the ground-water system through the valley floor at altitudes below 4,500 ft.

The movement of water to the Tertiary sedimentary rocks underlying the valley floor is influenced by the geologic characteristics and hydrologic parameters of the preTertiary sedimentary rocks at the higher altitudes. Fractured and weathered limestone, talus, and rock fragments on steep slopes bordering the basin receive rainfall and snowmelt and discharge it through springs near the base of the mountains and by underflow to the Tertiary sedimentary rocks in the valley. Snowmelt seldom directly reaches the network of stream channels that have formed at low altitudes, as evidenced by poorly developed stream channels at the higher altitudes.

Ground water moves from areas of recharge, down the hydraulic gradient, to areas of discharge. The rate of movement depends on the hydraulic conductivity of the material through which water moves and the slope of the hydraulic gradient.

Water from the pre-Tertiary sedimentary rocks, which border the basin and are thought to underlie the Tertiary sedimentary rocks, discharges naturally through springs and seeps and as leakage, both laterally and vertically upward, into the Tertiary sedimentary rocks. Typical, and most

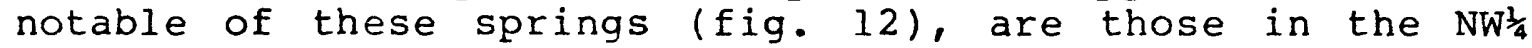
sec. 18, T. $10 \mathrm{~S} .$, R. $32 \mathrm{E}$., which contribute a large part of the perennial flow to East Fork Rock Creek. Water from the Tertiary sedimentary rocks discharges naturally into the stream system through springs and seeps on the valley floor, as direct evaporation where the water table is at or near land surface, as transpiration, and as underflow northward.

Additional discharge occurs through springs near the base of the Pleistocene gravel where the gravel contacts underlying Tertiary sedimentary rocks. Most of this water is derived from direct precipitation, which percolates through the gravel more rapidly than it can infiltrate the underlying rocks. Some of the springs are intermittent; some are perennial. Where they are perennial, local perched water-table aquifers have sufficient areal extent to maintain perennial spring flow. Some of these springs discharge to small streams that flow a distance of only several feet before they disappear into the ground. Most springs occur 


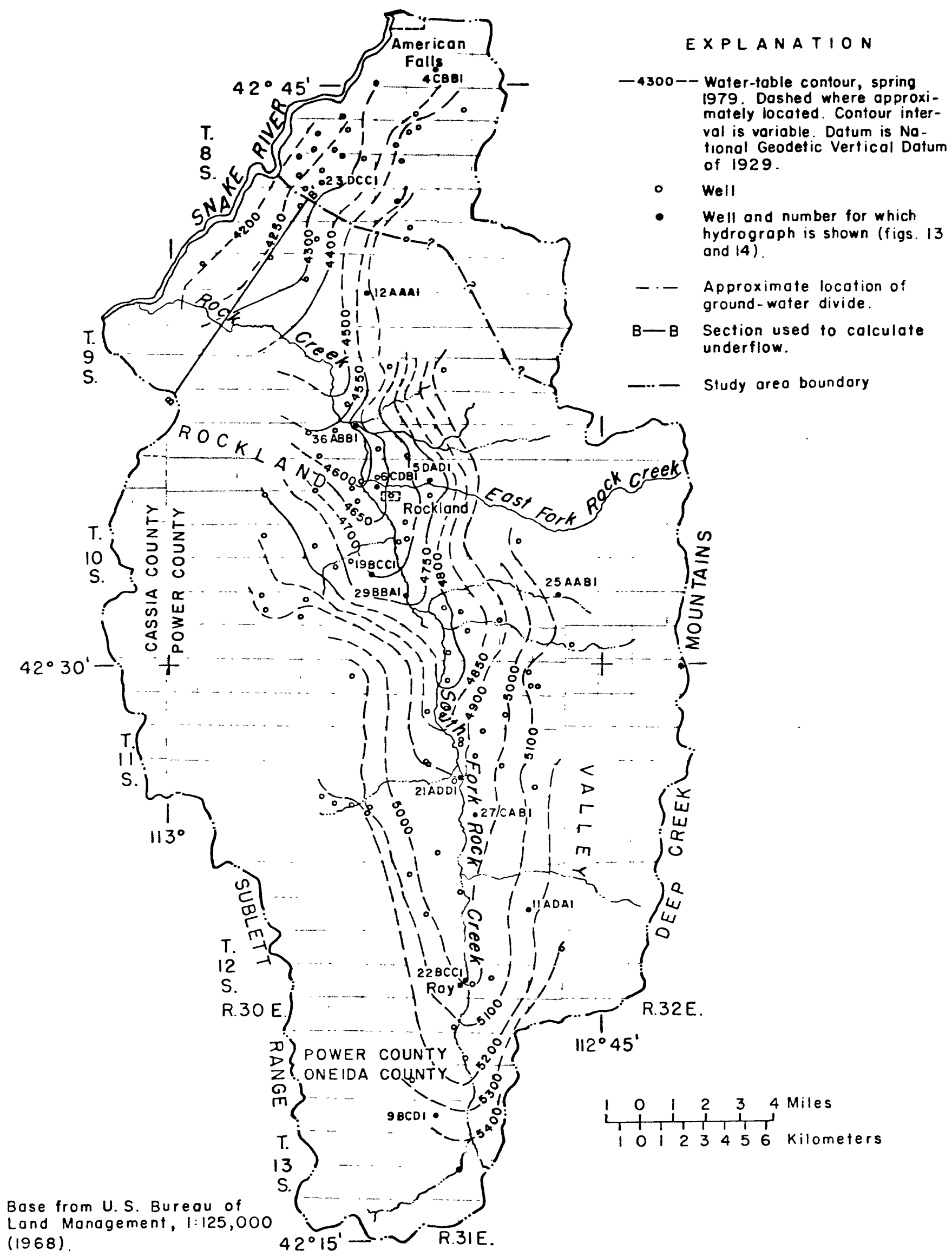

Figure 12. - Water-table contours and well locations. 
on the eastern side of Rockland basin, from T. 9 S., R. 31 E., through T. 11 S., R. 31 E. In comparison, few springs occur on the western side of the basin and their discharge rates generally are less than $5 \mathrm{gal} / \mathrm{min}$.

In the spring of 1979, prior to the start of the irrigation season, water-level measurements were made in 122 wells (table 4). These measurements were used to draw the water-table contour map in figure 12. In general, ground water moves perpendicular to and downgradient from the contours. Ground water generally follows the surface drainage toward major stream channels, then moves generally northward in the direction of flow in Rock Creek.

The average water-table gradient for the valley is about $25 \mathrm{ft} / \mathrm{mi}$, and slope is toward the mouth of Rock Creek. About 8-10 $\mathrm{mi}$ above the mouth of Rock Creek, the gradient flattens. The gradient again steepens downstream toward the mouth of Rock Creek and averages $43 \mathrm{ft} / \mathrm{mi}$ (near section $B-B^{\prime}$, fig. 12 ).

\section{Water-Level Fluctuations}

Ground-water levels in wells respond to changes in recharge to and discharge from the ground-water reservoir. If recharge to an aquifer exceeds discharge, water levels, with time, will rise. Conversely, if discharge exceeds recharge, water levels eventually will declinew Generally, water levels rise in late winter and early spring, when recharge from snowmelt and early spring rains is greatest, and decline in summer, when discharge owing to pumpage and ET is greatest. The periodicity of the fluctuations varies throughout the basin, depending on distance of the aquifer to recharge and discharge areas. For example, in areas where ground water is pumped for irrigation, annual low water levels usually occur in late summer, near the end of the irrigation season. Where surface-water irrigation is predominant, annual high water levels occur in late summer, owing to recharge from irrigation percolation and canal leakage. Where surface-water and ground-water irrigated areas overlap, mixed combinations of fluctuations may occur.

As part of this study, 12 wells were selected to monitor water-level fluctuations. Two wells were equipped with continuous recorders; their hydrographs are shown in figure 13. Ten wells were measured periodically; their hydrographs are shown in figure 14. Locations of the wells are shown in figure 12. Well los-3lE-6CDBl (fig. 13) is 14.2 ft deep and is completed in the Holocene alluvial 
Altitude: From U.S. Geological Survey topographic maps and field surveys; datum is National Geodetic Vertical Datum of 1929.

Well Depth: Reported, in feet below 1 and surface.

Casing Depth: Bottom of casing to nearest foot below land surface, or to first perforation where well finlsh (next column) is shown as $P$.

We11 finish: 0 - Open end, P - Perforated, $T$ - Sand point, $x$ - Open holé.
Water level: Measured, in feet below land surface.

Use of water: H-Domestic, I - Irrigation, O - Observation, P - Public supply, S - Stock, U - Unused.

Remarks: $\quad D L$ - Driller's log, WQ - water-quality analysis.

Notation: -- = No data available.

Casing

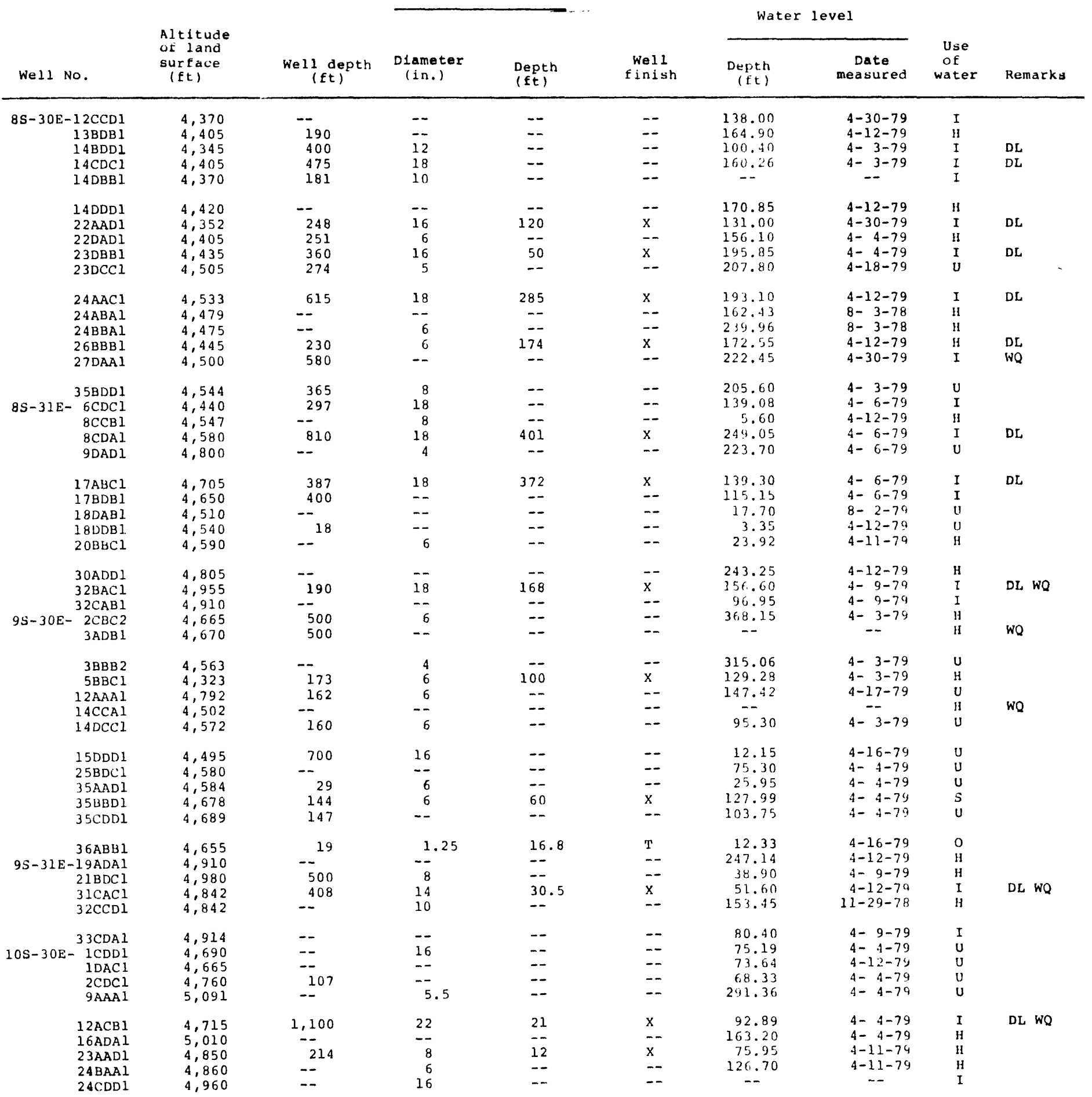




\begin{tabular}{|c|c|c|c|c|c|c|c|c|c|}
\hline \multirow[b]{3}{*}{ Well No. } & \multirow{3}{*}{$\begin{array}{l}\text { Altitude } \\
\text { of land } \\
\text { ourface } \\
\quad(f t)\end{array}$} & \multirow{3}{*}{$\begin{array}{l}\text { Wel1 depth } \\
\text { ( } f t)\end{array}$} & \multicolumn{2}{|c|}{ Casing } & \multirow{3}{*}{$\begin{array}{c}\text { Well } \\
\text { finish }\end{array}$} & \multirow{2}{*}{\multicolumn{2}{|c|}{ ivater level }} & \multirow{3}{*}{$\begin{array}{l}\text { Use } \\
\text { of } \\
\text { water }\end{array}$} & \multirow[b]{3}{*}{ Remarks } \\
\hline & & & \multirow{2}{*}{$\begin{array}{l}\text { Diameter } \\
\text { (in.) }\end{array}$} & \multirow{2}{*}{$\begin{array}{l}\text { Depth } \\
(f t)\end{array}$} & & & & & \\
\hline & & & & & & $(\mathrm{ft})$ & measured & & \\
\hline $\begin{array}{r}105-30 \mathrm{E}-25 \mathrm{BAA} 1 \\
25 \mathrm{BAA} 2 \\
26 \mathrm{BBC1} \\
27 \mathrm{DAD} 1 \\
28 \mathrm{AAB} 1\end{array}$ & $\begin{array}{l}4,960 \\
4,967 \\
5,054 \\
5,130 \\
5,070\end{array}$ & $\begin{array}{r}615 \\
650 \\
-- \\
240 \\
--\end{array}$ & $\begin{array}{r}20 \\
16 \\
-- \\
-- \\
5\end{array}$ & $\begin{array}{r}200 \\
250 \\
-- \\
-- \\
--\end{array}$ & $\begin{array}{l}P \\
P \\
-- \\
-- \\
--\end{array}$ & $\begin{array}{l}235.52 \\
251.70 \\
173.98 \\
228.16 \\
190.58\end{array}$ & $\begin{array}{l}4-11-79 \\
6-13-79 \\
4-11-79 \\
i-11-79 \\
4-11-79\end{array}$ & $\begin{array}{l}I \\
I \\
U \\
U \\
S\end{array}$ & $\begin{array}{l}\text { DL } \\
\text { DL }\end{array}$ \\
\hline $\begin{array}{r}28 D A A 1 \\
31 \mathrm{CCA} 1 \\
10 \mathrm{~S}-31 \mathrm{E}-\quad 4 \mathrm{CAD} 1 \\
5 \mathrm{DAD} 1 \\
6 \mathrm{CAB} 1\end{array}$ & $\begin{array}{l}5,177 \\
5,480 \\
4,800 \\
4,750 \\
4,682\end{array}$ & $\begin{array}{l}-- \\
-- \\
-- \\
17 \\
405\end{array}$ & $\begin{array}{l}-- \\
6 \\
6 \\
1.25 \\
16\end{array}$ & $\begin{array}{c}-- \\
-- \\
373\end{array}$ & $\begin{array}{l}-- \\
-- \\
-- \\
\mathrm{T}\end{array}$ & $\begin{array}{r}286.50 \\
277.68 \\
31.45 \\
7.93 \\
59.25\end{array}$ & $\begin{array}{l}4-11-79 \\
8-31-78 \\
4-12-79 \\
4-17-79 \\
4-12-79\end{array}$ & $\begin{array}{l}0 \\
U \\
H \\
0 \\
I\end{array}$ & DL \\
\hline $\begin{array}{r}6 \mathrm{CDB} 1 \\
7 \mathrm{ABB} 1 \\
8 \mathrm{AAA} 1 \\
8 \mathrm{CCB} 1 \\
14 \mathrm{ACC} 1\end{array}$ & $\begin{array}{l}4,644 \\
4,690 \\
4,770 \\
4,720 \\
5,220\end{array}$ & $\begin{array}{c}14 \\
401 \\
127 \\
-- \\
--\end{array}$ & $\begin{array}{l}1.25 \\
12 \\
6 \\
-- \\
--\end{array}$ & $\begin{array}{l}11.7 \\
110 \\
79 \\
-- \\
--\end{array}$ & $\begin{array}{l}T \\
P \\
X \\
-- \\
--\end{array}$ & $\begin{array}{r}5.30 \\
170.65 \\
52.85 \\
62.10 \\
97.50\end{array}$ & $\begin{array}{r}4-18-79 \\
10-19-78 \\
4-9-79 \\
5-1-79 \\
4-4-79\end{array}$ & $\begin{array}{l}0 \\
P \\
S \\
I \\
S\end{array}$ & $\begin{array}{l}\text { DL WQ } \\
\text { DL }\end{array}$ \\
\hline $\begin{array}{l}17 \mathrm{BCD} 1 \\
18 \mathrm{ADD} 1 \\
19 \mathrm{BCC} 1 \\
25 \mathrm{AAB} 1 \\
27 \mathrm{DDAl}\end{array}$ & $\begin{array}{l}4,710 \\
4,695 \\
4,842 \\
5,187 \\
4,965\end{array}$ & $\begin{array}{l}-- \\
-- \\
1150 \\
--\end{array}$ & $\begin{array}{r}-- \\
8 \\
16 \\
-- \\
6\end{array}$ & $\begin{array}{c}-- \\
200 \\
-- \\
--\end{array}$ & $\begin{array}{l}-- \\
-- \\
P \\
--\end{array}$ & $\begin{array}{r}30.88 \\
10.61 \\
146.36 \\
18.61 \\
92.76\end{array}$ & $\begin{array}{l}4-12-79 \\
4-12-79 \\
4-17-79 \\
4-17-79 \\
4-10-79\end{array}$ & $\begin{array}{l}\mathrm{I} \\
\mathrm{H} \\
\mathrm{U} \\
\mathrm{S} \\
\mathrm{H}\end{array}$ & $\begin{array}{l}\text { WQ } \\
\text { DL }\end{array}$ \\
\hline $\begin{array}{l}28 B D C 1 \\
28 D A B 1 \\
29 B B A 1 \\
33 C D A 1 \\
34 \mathrm{BBB} 1\end{array}$ & $\begin{array}{l}4,810 \\
4,921 \\
4,730 \\
4,802 \\
4,901\end{array}$ & $\begin{array}{l}-- \\
-- \\
335 \\
--\end{array}$ & $\begin{array}{l}-- \\
- \\
16 \\
4\end{array}$ & $\begin{array}{l}-- \\
-- \\
15.4 \\
34 \\
--\end{array}$ & $\begin{array}{l}-- \\
-- \\
T \\
P \\
--\end{array}$ & $\begin{array}{r}23.90 \\
114.20 \\
12.88 \\
21.28 \\
75.85\end{array}$ & $\begin{array}{l}4-11-79 \\
4-11-79 \\
4-17-79 \\
4-11-79 \\
4-10-79\end{array}$ & $\begin{array}{l}H \\
I \\
O \\
I \\
U\end{array}$ & DL WQ \\
\hline $\begin{array}{r}10 \mathrm{~S}-32 \mathrm{E}-31 \mathrm{CBA} 1 \\
11 \mathrm{~S}-30 \mathrm{E}-1 \mathrm{AACl} \\
25 \mathrm{ACB} 1 \\
25 \mathrm{BBCl} \\
26 \mathrm{ABAl}\end{array}$ & $\begin{array}{l}5,290 \\
5,260 \\
5,370 \\
5,480 \\
5,586\end{array}$ & $\begin{array}{l}-- \\
-- \\
-- \\
--\end{array}$ & $\begin{array}{r}6 \\
4 \\
-- \\
6 \\
4\end{array}$ & $\begin{array}{l}-- \\
-- \\
-- \\
--\end{array}$ & $\begin{array}{l}-- \\
-- \\
-- \\
-- \\
--\end{array}$ & $\begin{array}{r}105.43 \\
89.33 \\
123.90 \\
277.55 \\
347.50\end{array}$ & $\begin{array}{l}4-10-79 \\
4-11-79 \\
4-10-79 \\
4-10-79 \\
4-10-79\end{array}$ & $\begin{array}{l}\mathrm{S} \\
\mathrm{U} \\
\mathrm{U} \\
\mathrm{U} \\
\mathrm{U}\end{array}$ & \\
\hline $\begin{array}{r}11 S-31 E-1 C B C 1 \\
2 A D A 1 \\
2 D A D 1 \\
4 C A A 1 \\
8 A D D 1\end{array}$ & $\begin{array}{l}5,200 \\
5,220 \\
5,210 \\
4,816 \\
4,860\end{array}$ & $\begin{array}{c}600 \\
-- \\
-- \\
-33\end{array}$ & $\begin{array}{r}16 \\
6 \\
4 \\
-- \\
8\end{array}$ & $\begin{array}{l}70 \\
-- \\
-- \\
-- \\
--\end{array}$ & $\begin{array}{l}P \\
-- \\
-- \\
-- \\
--\end{array}$ & $\begin{array}{l}81.70 \\
86.55 \\
86.10 \\
38.16 \\
21.63\end{array}$ & $\begin{array}{l}5-25-79 \\
4-10-79 \\
4-10-79 \\
9-1-78 \\
4-12-79\end{array}$ & $\begin{array}{l}I \\
S \\
U \\
H \\
U\end{array}$ & DL WQ \\
\hline $\begin{array}{r}9 \mathrm{BDD} 1 \\
9 \mathrm{CAAl} \\
11 \mathrm{CBAl} \\
15 \mathrm{ABB} 1 \\
15 \mathrm{CDB} 1\end{array}$ & $\begin{array}{l}4,865 \\
4,865 \\
5,030 \\
5,002 \\
4,970\end{array}$ & $\begin{array}{l}-- \\
-- \\
-- \\
604 \\
36\end{array}$ & $\begin{array}{r}-- \\
-- \\
-- \\
16 \\
6\end{array}$ & $\begin{array}{l}-- \\
-- \\
-- \\
65 \\
--\end{array}$ & $\begin{array}{l}-- \\
-- \\
-- \\
P \\
--\end{array}$ & $\begin{array}{l}22.50 \\
26.62 \\
35.20 \\
61.04 \\
23.38\end{array}$ & $\begin{array}{l}4-12-79 \\
9-1-78 \\
4-5-79 \\
4-5-79 \\
4-5-79\end{array}$ & $\begin{array}{l}I \\
H \\
H \\
I \\
U\end{array}$ & \\
\hline $\begin{array}{l}16 \mathrm{ADAl} \\
16 \mathrm{ADA} 2 \\
16 \mathrm{ADD} 1 \\
17 \mathrm{DDD} 1 \\
21 \mathrm{ADCl}\end{array}$ & $\begin{array}{l}4,880 \\
4,880 \\
4,880 \\
4,975 \\
4,922\end{array}$ & $\begin{array}{r}125 \\
-- \\
60 \\
124 \\
530\end{array}$ & $\begin{array}{r}20 \\
6 \\
-- \\
-- \\
12\end{array}$ & $\begin{array}{l}20 \\
-- \\
-- \\
-- \\
--\end{array}$ & $\begin{array}{l}P \\
-- \\
-- \\
-- \\
P\end{array}$ & $\begin{array}{r}7.52 \\
26.05 \\
10.23 \\
86.69 \\
16.42\end{array}$ & $\begin{array}{l}4-5-79 \\
9-2-78 \\
4-5-79 \\
4-5-79 \\
4-5-79\end{array}$ & $\begin{array}{l}\mathrm{I} \\
\mathrm{H} \\
\mathrm{H} \\
\mathrm{U} \\
\mathrm{I}\end{array}$ & $\begin{array}{l}\text { DL WQ } \\
\text { WQ }\end{array}$ \\
\hline $\begin{array}{l}21 \mathrm{ADD} 1 \\
23 \mathrm{BBAl} \\
23 \mathrm{BBA} 2 \\
24 \mathrm{CBCl} \\
27 \mathrm{CABl}\end{array}$ & $\begin{array}{l}4,900 \\
5,083 \\
5,081 \\
5,235 \\
4,966\end{array}$ & $\begin{array}{c}18 \\
-240 \\
106 \\
220\end{array}$ & $\begin{array}{l}1.25 \\
-- \\
16 \\
4 \\
12\end{array}$ & $\begin{array}{r}16 \\
-- \\
170 \\
89 \\
--\end{array}$ & $\begin{array}{l}T \\
-- \\
X \\
X \\
--\end{array}$ & $\begin{array}{r}9.49 \\
9.73 \\
9.83 \\
79.20 \\
30.48\end{array}$ & $\begin{array}{l}4-18-79 \\
5-1-79 \\
5-1-79 \\
4-5-79 \\
4-18-79\end{array}$ & $\begin{array}{l}0 \\
I \\
I \\
U \\
U\end{array}$ & DL \\
\hline $\begin{array}{r}30 \mathrm{BCAl} \\
30 \mathrm{BCCl} \\
12 \mathrm{~S}-31 \mathrm{E}-\quad 4 \mathrm{DDAl} \\
5 \mathrm{BDAl} \\
8 \mathrm{ADD} 1\end{array}$ & $\begin{array}{l}5,290 \\
5,322 \\
5,065 \\
5,100 \\
5,245\end{array}$ & $\begin{array}{r}1,120 \\
273 \\
-- \\
72 \\
281\end{array}$ & $\begin{array}{r}16 \\
6 \\
5 \\
- \\
5\end{array}$ & $\begin{array}{r}-- \\
273 \\
-- \\
--\end{array}$ & $\begin{array}{l}-- \\
0 \\
-- \\
--\end{array}$ & $\begin{array}{r}243.89 \\
143.13 \\
70.65 \\
65.30 \\
250.00\end{array}$ & $\begin{array}{l}4-5-79 \\
4-5-79 \\
4-2-79 \\
4-5-79 \\
4-\quad 2-79\end{array}$ & $\begin{array}{l}\mathrm{I} \\
\mathrm{H} \\
\mathrm{H} \\
\mathrm{U} \\
\mathrm{U}\end{array}$ & $\begin{array}{l}\text { DL WQ } \\
\text { WQ }\end{array}$ \\
\hline $\begin{array}{l}11 \mathrm{ADA} 1 \\
13 \mathrm{ADD} 1 \\
21 \mathrm{CCD} 1 \\
22 \mathrm{ADCl} \\
22 \mathrm{BBB} 1\end{array}$ & $\begin{array}{l}5,247 \\
5,696 \\
5,205 \\
5,223 \\
5,073\end{array}$ & $\begin{array}{r}280 \\
400 \\
-- \\
-240 \\
--\end{array}$ & $\begin{array}{l}6 \\
6 \\
6 \\
6 \\
6\end{array}$ & $\begin{array}{r}166 \\
-- \\
40 \\
--\end{array}$ & $\begin{array}{l}-- \\
\bar{x} \\
--\end{array}$ & $\begin{array}{c}84.25 \\
110.43 \\
207.84 \\
75.55\end{array}$ & $\begin{array}{l}4-5-79 \\
-- \\
4-2-79 \\
4-2-79 \\
4-2-79\end{array}$ & $\begin{array}{l}\text { U } \\
\text { S } \\
H \\
H \\
H\end{array}$ & DL, WQ \\
\hline $\begin{array}{r}22 \mathrm{BCCl} \\
22 \mathrm{CAB1} \\
29 \mathrm{DCAl} \\
34 \mathrm{CCB1} \\
13 \mathrm{~S}-31 \mathrm{E}-\quad 5 \mathrm{ACB} 1\end{array}$ & $\begin{array}{l}5,104 \\
5,120 \\
5,300 \\
5,220 \\
5,315\end{array}$ & $\begin{array}{l}106 \\
125 \\
188 \\
116 \\
80\end{array}$ & $\begin{array}{r}-- \\
6 \\
5 \\
48 \\
5\end{array}$ & $\begin{array}{l}-- \\
-- \\
-- \\
--\end{array}$ & $\begin{array}{l}-- \\
-- \\
-- \\
-- \\
--\end{array}$ & $\begin{array}{r}94.67 \\
121.80 \\
168.10 \\
97.85 \\
37.53\end{array}$ & $\begin{array}{l}4-18-79 \\
4-2-79 \\
4-2-79 \\
4-2-79 \\
4-10-79\end{array}$ & $\begin{array}{l}u \\
U \\
U \\
U \\
U\end{array}$ & \\
\hline $\begin{array}{r}9 B C D 1 \\
21 A A A 1\end{array}$ & $\begin{array}{l}5,435 \\
5,529\end{array}$ & -- & $\begin{array}{r}4 \\
--\end{array}$ & -- & -- & $\begin{array}{r}104.43 \\
46.57\end{array}$ & $\begin{array}{l}4-18-79 \\
4-10-79\end{array}$ & $\begin{array}{l}\mathrm{U} \\
\mathrm{U}\end{array}$ & \\
\hline
\end{tabular}



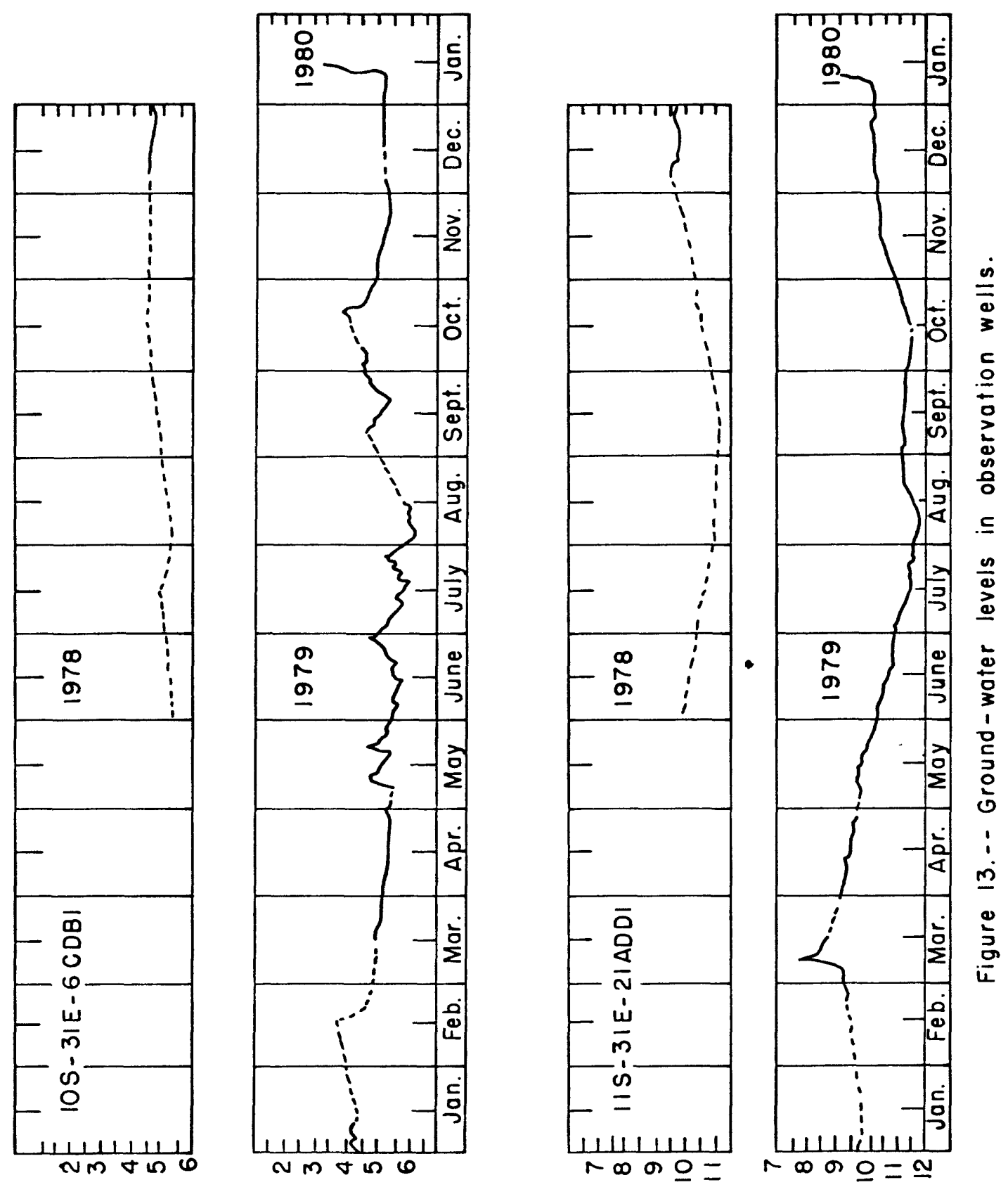

$\exists \supset \forall \exists \forall \cap S$ ON $\forall 7$ MO

$\perp \exists \exists \exists \mathrm{NI}$ ' $\forall \exists \perp \forall M$ O 

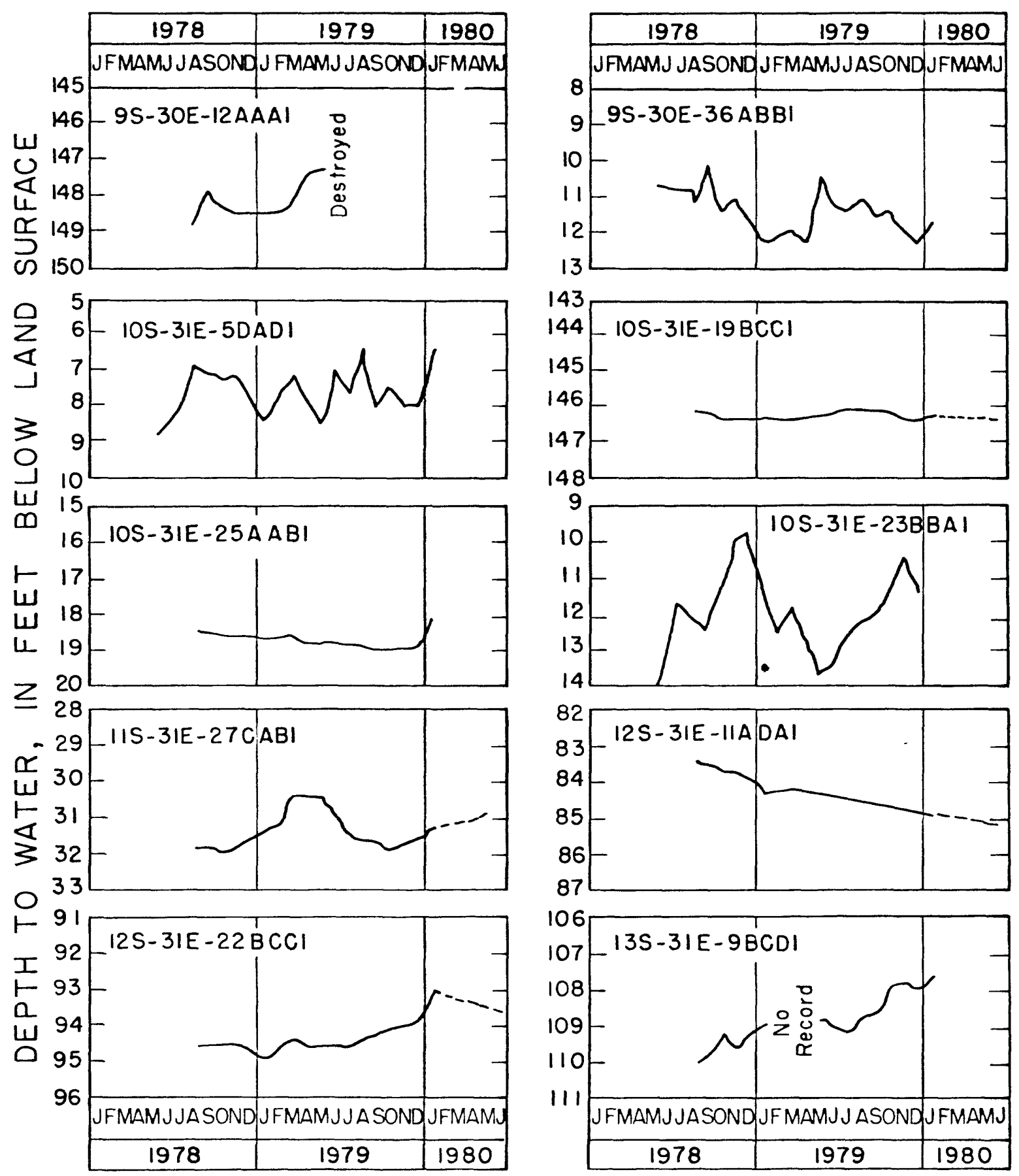

Figure 14. -- Ground-water levels in selected wells. 
aquifer adjacent to East Fork Rock Creek in a predominantly surface-water irrigated area. Although the magnitude of fluctuations is not great, the trend shows that water levels rise gradually from August through January and decline gradually from March to July. Well lis-3lE-2lADDl (fig. 13) is $18.4 \mathrm{ft}$ deep and is completed in the Holocene alluvial aquifer adjacent to Rock Creek. This well is near a well that withdraws water for irrigation, and the water level in the observation well responds to pumping in the irrigation well. Here the water levels decline gradually through the early part of the irrigation season and remain low through the end of the season, when they begin a gradual rise. The declining effects owing to pumpage may be dampened, however, for the water withdrawn from the nearby well is spread for irrigation in the vicinity; hence, part of it may return to the water table as seepage from fields.

The hydrographs of both wells in figure 13 and of several wells in figure 14 show abrupt water-level rises in January 1980. These rises were caused by a mid-winter storm, during which substantial flooding occurred throughout the basin. Stream flood plains were inundated, and part of the water that did not $r$ un off in the streams percolated to the water table to recharge the Holocene alluvial and Tertiary sedimentary-rock aquifers.

Hydrographs for the wells measured from 1978 to 1980 during this study are shown in figure 14. The hydrographs demonstrate the wide variation in water-level fluctuations in different parts of the basin and show that the annual range from high to low water levels is generally less than $4 \mathrm{ft}$. The duration of the records is too short and supporting data are too meager to determine, with any degree of certainty, the causes for the particular fluctuations at any one place; but wells 10S-31E-19BCCl, 10S-31E25AABl, and 12S-3IE-IIADAl show little water-level fluctuations. Well 10S-31E-19BCCl is $815 \mathrm{ft}$ deep and is completed mostly in clay. Clay transmits water slowly and will lag in response to any recharge or discharge stress placed on the ground-water system. This lag is magnified in a largediameter casing (or open hole) to where any due response would be made almost imperceptible, which is probably the case for this well. Wells I0S-3IE-25AABl and 12S-31E-IIADAI lack seasonally responsive fluctuations, but they do show perceptible trends.

The small annual range of water-level fluctuations shown on the hydrographs in figures 13 and 14 suggests that no great stress by pumping is presently being put on the ground-water resources in the basin. The well hydrographs indicate no permanent lowering of water levels for 
this short period of record. However, these wells should be measured periodically to monitor long-term hydrologic effects on the basin.

\section{Aquifer Characteristics}

Transmissivity $(\mathrm{T})$ is the rate at which water moves through a unit width of an aquifer under a unit hydraulic gradient. The $T$ of an aquifer can be determined by multiplying the thickness of the aquifer by its average hydraulic conductivity and(or) by using a number of other methods, most of which are described in Lohman (1979). Generally, T is determined from aquifer pump-test data; however, only meager pump-test data are available for aquifers in the valley. Drillers' logs frequently include well production tests, which report pumping rate and level of drawdown. The time period of these tests often is too short to allow determination of $T$ values, but the SC (specific capacity) for the well can be determined. The SC of a well is the yield in gallons per minute per foot of drawdown. Using SC values, T's were estimated for many of the wells by using the empirically derived graphs shown in walton (1962). Values of T's calculated from SC data from irrigation wells completed in Tertiary sedimentary rocks ranged from less than 150 to $10,500 \mathrm{ft} \%$. Values of $\mathrm{T}$ calculated using SC data from wells completed in Quaternary-Tertiary volcanic rocks (basalt) to the north, outside Rockland basin, ranged from 3,900 to $48,000 \mathrm{ft}^{2} / \mathrm{d}$.

Assuming an average SC of $75 \mathrm{gal} / \mathrm{min}$ per foot of drawdown, as estimated from averaged pumping rates and drawdowns in the northern area (wells completed in volcanic rocks of Quaternary-Tertiary age), a $T$ value of 20,000 $\mathrm{ft}^{2} / \mathrm{d}$ is assumed to be representative of the basalt rocks in the northern part of Rockland basin (T. 8 S., R. 30-3I E.).

The pre-Tertiary sedimentary rocks are not regarded as having good potential for ground-water development, although southwest of Rockland, two wells completed in fractured 1 imestone are reported to yield 2,200 and 2,500 $\mathrm{gal} / \mathrm{min}$. However, these wells produce thermal water and are thought to have penetrated a fault zone, so they probably do not represent the development potential of the pre-Tertiary sedimentary rocks.

Another hydraulic characteristic used to describe the ground-water system is $S$ (storage coefficient), which is the volume of water an aquifer releases from or takes into storage per unit surface area of the aquifer per unit change in head. The $S$ of unconfined aquifers is virtually equal 
to the specific yield, as most of the water is released from storage by gravity drainage and expansion of the water. The $S$, or specific yield, of most unconfined aquifers ranges from about 0.1 to 0.3 and averages about 0.2 (Lohman, 1979, p. 8 ).

Determination of hydraulic characteristics of the Quaternary and Tertiary sedimentary deposits, considered as one hydrologic unit in this report, was limited to analysis of data from two wells (10S-31E-6CDBl and 11S-31E-2lADDI). Various periodic segments of record were observed for drawdown caused by nearby pumping wells. Using type curves from Boulton (1964, pl. 7, curve A), for an unconfined aquifer having anisotropic conditions, $a \mathrm{~T}$ of about 6,000 ft $2 / d$ and an $s$ of 0.15 were computed for the alluvial aquifer.

Additional aquifer analysis (method by Rorabaugh, 1964) was applied to observation well 11S-3IE-2lADDI by comparing water-level fluctuations (fig. 15) to stream recharge and discharge. The stream is $170 \mathrm{ft}$ from the well. Aquifer discharge from both sides of the stream was estimated from the change in stage. The $T$ value computed using Rorabaugh's method was $5,630 \mathrm{ft}^{2} / \mathrm{d}$, and the $S$ was 0.14 .

On the basis of the above determinations, a value of about $5,700 \mathrm{ft} 2 / \mathrm{d}$ probably represents the local average $T$ of the Quaternary-Tertiary sedimentary aquifer.

Analysis of water-level drawdown and recovery using the above methods allows evaluation of the short-and long-term discharge-recharge effects on the basis of aquifer response. Variables such as distance from the pumping well, type of aquifer, geologic composition, aquifer thickness and width, and boundary effects determine the type of curve to be used. In each case, the applied method reflected the effects of the stream as a recharging boundary.

\section{Underflow}

Underflow from Rockland basin occurs through basalt and localized clay and sand layers near the mouth of Rock Creek. The amount of underflow, $Q$, to the snake River was estimated by using the equation:

$$
Q=T I L
$$

where

$T=$ transmissivity, in feet squared per day,

$I=$ hydraulic gradient, in feet per mile, and

$\mathrm{L}=$ width, in miles, of the cross section through which underflow occurs. 


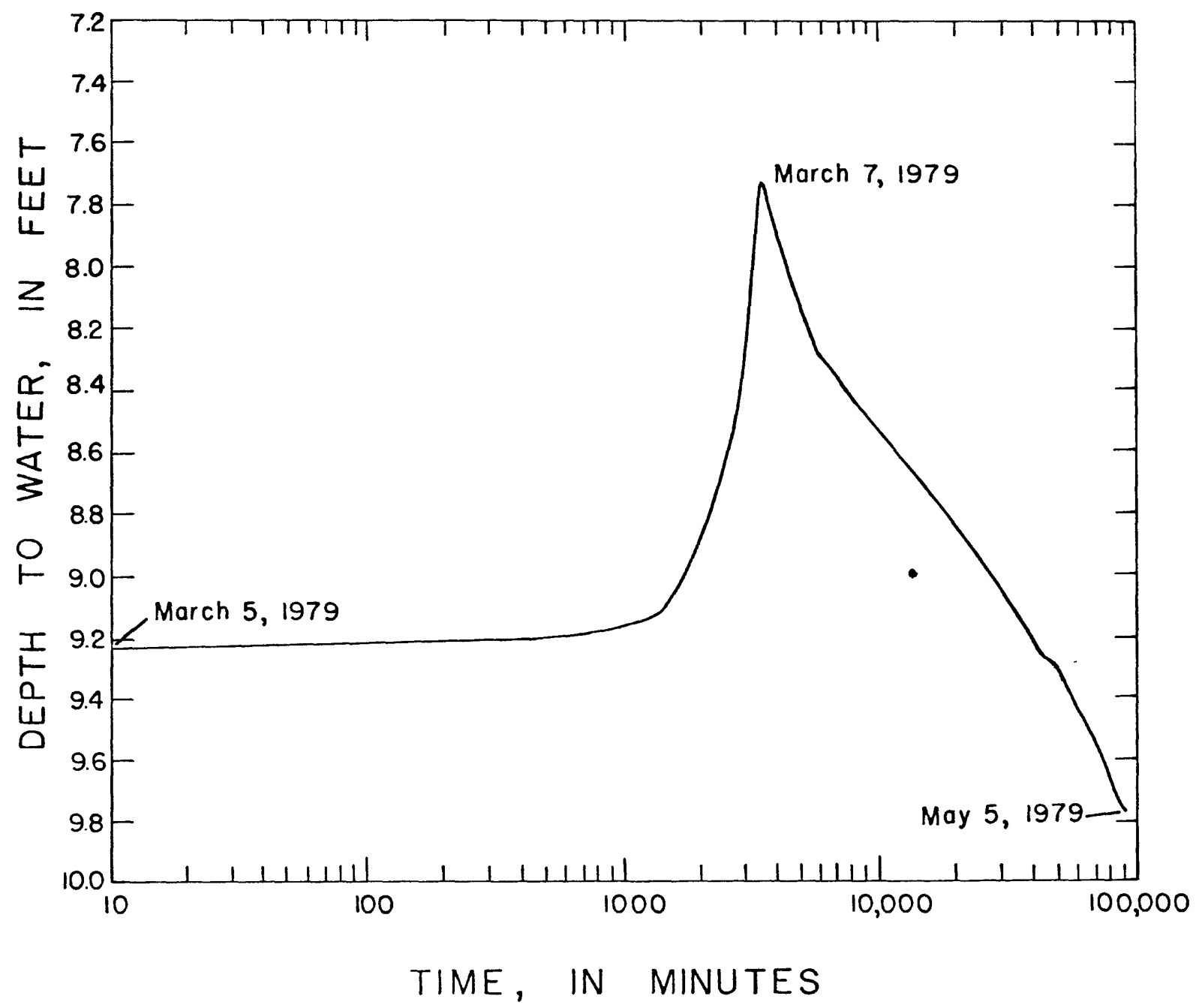

Figure 15.-- Water-level fluctuations in observation well IIS-3IE-2IADDI caused by flood recharge. 
Using the previously computed $T$ of $20,000 \mathrm{ft}^{2} / \mathrm{d}$, a hydraulic gradient of $43 \mathrm{ft} / \mathrm{mi}$ (determined from the water-level contour map), and a cross-section width of 7.0 $\mathrm{mi}$ (fig. 12), underflow from Rockland basin is computed to be 51,000 acre-ft/yr. This estimate agrees closely with the estimate of 50,000 acre-ft/yr made by Mundorff, Crosthwaite, and Kilburn (1964).

WATER USE

The principal use of water in the basin is for irrigation, followed by municipal, stock, and domestic supplies. Irrigation accounts for about 99 percent of the total water use. Of nearly 107,000 acres of arable land in the basin, about 12,000 acres was irrigated in 1979 (see fig. 3) and about 15,500 acre-ft, or about 1.3 acre-ft/acre, of ground and surface water was used. About one-fourth of the irrigation water was supplied by ground water from wells; the remainder was from surface-water sources and from springs.

The actual quantity of water used for irrigation varies from year to year depending on the availability of supply. For example, in dry years when streamflow is low, either more ground water is pumped to augment the short supply or less land is irrigated. About 3,600 acres was left unseeded after being plowed for the 1979 growing season.

Irrigated land in Power County (which includes about 85 percent of Rockland basin) produces 3-4 times the amount of wheat than dryfarmed land produces (U.S. Department of Agriculture, 1966). Development and growth of agricultural land, specifically irrigated land, are shown in figure 16. Conversion of nonirrigated land to irrigated land in Power County has tripled since the 1950's. Because 91,000 acres of nonirrigated farmland is situated in Rockland basin, an increase in demand for water supplies can be expected.

\section{Consumptive Water Use and Net Irrigation Requirements}

Any increase in consumptive water use for ET by crops will reduce the amount of water normally available for streamflow and ground-water discharge.

Various crops have different consumptive water-use requirements, depending on factors that affect ET and plant maturity during the growing season. Average consumptive 


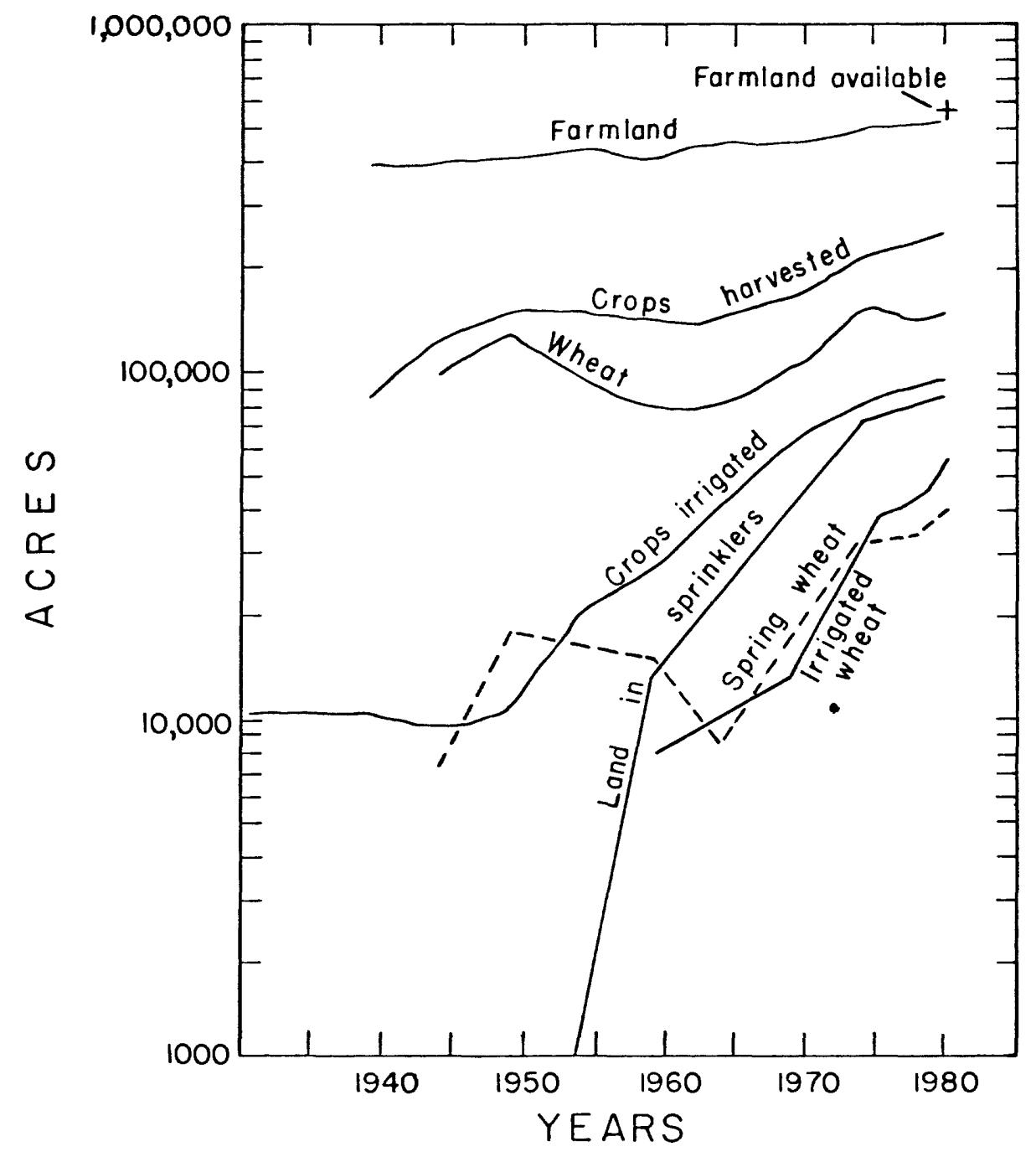

Figure 16.-- Agricultural land use in Power County.

(Data from U.S. Department of Agriculture census reports.) 
water-use requirements for winter and spring wheat in the Pocatello area are 20.1 and 17.4 in., respectively (Sutter and Corey, 1970). The Blaney-Criddle formula (U.S. Soil Conservation Service, 1967), which was used to compute the above figures, also was applied to Rockland basin by adjusting temperature, precipitation, and daylight hours in American Falls to conditions in the basin. The growth stage of spring wheat on the basis of plant maturity (U.S. Soil Conservation Service, 1967, p. 76) coincided with pumpage demand (from power-consumption records). Using the BlaneyCriddle formula, as applied to Rockland data, the estimated average annual water consumption for winter and spring wheat is 20 in., with more spring wheat than winter wheat being irrigated in Rockland basin.

Average rainfall in the Pocatello area during the irrigation season is 2.8 and 3.6 in. for winter and spring, respectively. Thus, the net annual irrigation requirements (or consumptive use minus the rainfall for the irrigation period) for winter and spring wheat in the Pocatello area are 17.3 in. (20.1 in. minus $2.8 \mathrm{in.)}$ and $13.8 \mathrm{in.}(17.4 \mathrm{in}$. minus 3.6 in.), respectively. Estimated rainfall for Rockland basin during the irrigation season is 3.5 in., and the net annual irrigation requirement is 16.5 in. $(20.0$ in. minus 3.5 in.), or 1.3 acre-ft/acre for both wheat crops.

The rate of surface-water application for Power County is estimated to be 2.1 acre-ft/acre (U.S. Department of Agriculture, 1966). This figure is considerably higher than the net annual irrigation requirement of 1.3 acre-ft. However, it is estimated from hydrograph comparison of two sites on the East Fork Rock Creek, during 1955-64, that about one-fourth of the upstream diverted water (adjusted for seepage losses) returns directly to the lower reaches of the East Fork late in the growing season.

Assuming that one-fourth of the applied water is not consumptively used, and that 3.5 in. of normal rainfall during the growing season is available, then the estimated irrigation requirement from ground-water and surface-water sources would remain about 1.3 acre-ft/acre 175 percent of 2.1 acre-ft/acre minus 0.29 acre-ft/acre of rainfall equals 1.3 acre-ft/acre).

\section{Surface-Water Use}

Principal sources of surface water available for irrigation of about 9,000 acres are East Fork Rock Creek, Rock Creek, and several small springs. Additional irrigation water not supplied by diversions is pumped directly from the stream and applied to adjacent land tracts. 
Monthly streamflow measurements from Rock Creek and East Fork Rock Creek for periods of record 1955-79 were used to estimate the mean streamflow available for irrigation during the growing season. Surface-water discharge for May to October 1979 was estimated to be 13,000 acre-ft, which included additional runoff inflow above site 13077650 . Adjusting the 1979 discharge figure by subtracting the excess runoff from summer storms, or nondivertible flows, the amount available in 1979 for irrigation was reduced to 11,700 acre-ft. The 1979 water year had sufficient surface flow to meet irrigation requirements of 9,000 acres $x 1.3$ acre-ft/acre, or about 12,000 acre-ft. However, during seasons of less runoff, additional irrigation requirements would have to be supplied by ground-water pumping. For example, surface-water discharge available for 1955-60 during May to October when diversion began and ended showed that the flow was about 8,900 acre-ft. The difference between 12,000 acre-ft and the flow of 8,900 acre-ft $(3,100$ acre-ft) must be supplied from ground-water sources, or the total irrigated acreage must be reduced.

\section{Ground-Water Use}

In 1979, about 17 wells were pumped to irrigate croplands in the study area. No records were kept by the irrigators of the amount of water pumped. Therefore, power-consumption records were obtained from the Idaho Power Company, from which total pumpage was calçulated. Ten of the pumped wells were powered by electricity and seven by diesel engines.

Measurements of flow discharge were made at the irrigation wells during the pumping season. Knowing the rate of discharge, total kilowatt hours consumed, and demand of each motor (kilowatts), total withdrawals were computed by means of the following formula:

$$
Q t=Q r \times \frac{K w H}{D}
$$

where

$$
\begin{aligned}
& \text { Qt = total withdrawals, in acre-feet, } \\
& \text { Qr = discharge rate, in acre-feet per hour, } \\
& \text { KwH = total power consumed, in kilowatt hours, and } \\
& \mathrm{D}=\text { demand of motor, in kilowatts. }
\end{aligned}
$$

For wells powered by diesel engines, pumpage withdrawals were determined by multiplying the average number of pumping hours for the irrigation season of all wells powered 
by electric motors by the discharge rate of each well. Computed withdrawals then were composited by areas within Rockland basin.

Rates of ground-water application, mainly by sprinklers, ranged from 0.72 acre-ft/acre in the southern part of the basin to 2.46 acre-ft/acre in the extreme northern part (T. 8 S., R. 30 E., 31 E.). The average rate of application for Rockland basin is 1.32 acre-ft/acre, similar to the net irrigation requirement of 1.3 acre-ft/acre previously estimated for wheat crops. Thus, estimated ground-water withdrawal to irrigate 2,700 acres in Rockland basin is 3,500 acre-ft/yr.

\section{Municipal, Domestic, and Stock Water Use}

Municipal and rural domestic use can be estimated by assuming an average rate of withdrawal per household. The town of Rockland uses about 35 acre-ft/yr ( 98 families at about $320 \mathrm{gal} / \mathrm{d}$ per family). Use of water for rural domestic purposes is estimated to be 20 acre-ft/yr, on the basis of a per-capita use rate of $150 \mathrm{gal} / \mathrm{d}$. Use of water by livestock is unknown but is small compared to irrigation volumes. Stock water is obtained mostly from springs or diverted surface water. The small amount consumed can be estimated. For example, the estimated 8,000 head of range cattle in Rockland basin would consume $6.3 \mathrm{gal} / \mathrm{d}$ per head, or about 56 acre-ft/yr.

\section{Water Budget}

The total quantity of water available for use in the $320-\mathrm{mi}^{2}$ basin was defined previously as water yield, or water remaining after evaporation and transpiration of natural vegetation. Numerically, these long-term values are:

$$
\begin{aligned}
& \text { Total precipitation }=17.3 \mathrm{in} . / \mathrm{yr} \text {, or } 295,000 \mathrm{acre}-\mathrm{ft} / \mathrm{yr} \\
& \text { Natural ET }=12.3 \mathrm{in} . / \mathrm{yr} \text {, or } 210,000 \text { acre-ft/yr } \\
& \text { Yield }=5.0 \mathrm{in} . / \mathrm{yr} \text {, or } 85,000 \text { acre-ft/yr }
\end{aligned}
$$

Part of the available water yield is consumed by irrigation, domestic, and livestock use. Any water not consumptively used leaves the basin as surface flow and underflow. Individual elements of the water budget for 1979 are: 
Ground water used for irrigation Surface water used for irrigation Municipal, domestic, and stock uses Surface-water outflow Underflow

Total

$$
\begin{aligned}
& =3,500 \text { acre-ft/yr } \\
& =12,000 \text { acre-ft/yr } \\
& =100 \text { acre-ft/yr } \\
& =19,800 \text { acre-ft/yr } \\
& =51,000 \text { acre }-\mathrm{ft} / \mathrm{yr} \\
& =86,400 \mathrm{acre}-\mathrm{ft} / \mathrm{yr}
\end{aligned}
$$

In comparing the 1979 water budget to the long-term yield of Rockland basin, water available in 1979 was 2 percent above normal. However, on the basis of the following assumptions, 1979 easily could be 2 percent less than normal: (1) Consumptive use of water for irrigation, municipal, domestic, and stock supplies during 1979 is typical of normal water use $(15,600$ acre-ft/yr): (2) longterm surface-water outflow averages 16.500 acre-ft/yr; (3) underflow of 51,000 acre-ft/yr is representative of longterm conditions; and (4) no significant change in water levels, hence storage, occurred in 1979.

Despite the relatively small error between budget elements for 1979 and the long-term yield, probable error in excess of 5 percent exists in any of the values. However, because of expected annual fluctuations in any of the elements used to determine yield, the estimate of 5.0 in./yr probably is still indicative of long-term water availability in Rockland basin.

\section{SURFACE-WATER/GROUND-WATER RELATIONS}

The surface- and ground-water resources of Rockland basin are intricately related. The movement of water from the land surface to the subsurface and back to the land surface occurs naturally in the basin, and the surfacewater/ground-water relations are an important hydrologic factor in the availability and use of water.

Flow in Rock creek is derived from overland runoff of precipitation and snowmelt, springfed tributaries, and ground-water discharge. Because of the lack of surface runoff from the surrounding mountains, overland flow in Rock Creek is derived mainly from precipitation and snowmelt on the valley floor. East Fork Rock Creek, whose flow is derived mainly from spring discharge, is the largest contributor of flow to Rock Creek. Ground-water discharge to Rock Creek is predominantly from the Holocene alluvial aquifer.

\section{Gaining and Losing Reaches in Rock Creek and East Fork Rock Creek}

The contribution of ground water (or base flow) was assessed by streamflow measurement at selected sites 
along Rock Creek and East Fork Rock Creek. Measurements were made between October 31 and November 2, 1978, when effects of irrigation were minimal. Locations of measuring sites, discharge, and cumulative apparent gains and losses to ground water in the two streams are illustrated in figure 17. Measuring sites are numbered in downstream order, with measured inflows and outflows noted.

Rock Creek generally gains or receives ground-water discharge between measuring sites 2-12 (fig. 17). Below measuring site 12 to the Rock Creek near American Falls site, no connection exists between surface and ground water. East Fork Rock Creek gains from the ground-water system in its upper reach (sites 1, 2, and 3) and generally loses to ground water in its middle (site 4) and lower (sites 8,10 , and 12 ) reaches.

\section{Effects of Ground-Water Pumpage on Surface-Water Flows}

Pumping of wells adjacent to a stream where there is direct hydraulic connection with an aquifer will result in a decrease in streamflow. The degree to which streamflow is affected depends on proximity of the well to the stream, rate of recharge, quantity of water pumped, and ability of the aquifer and streambed to transmit water. It is the withdrawal of ground water at the expense of appropriated downstream water that is of concern to surface-water users in Rockland basin.

No quantitative measure of streamflow depletion resulting from ground-water withdrawal has been made in Rockland basin. The rate and volume of stream depletion during and after pumping of a nearby well were described by Jenkins (1970) for a system in which the surface-water/ground-water regime was in equilibrium. Figure 18, constructed using Jenkins's method, for the alluvial aquifer in Rockland basin having average $T$ values of $5,700 \mathrm{ftz} / \mathrm{d}$ and an average $S$ of 0.14 , shows the percentage of surface water derived from Rock Creek in water pumped from a well placed at selected distances from Rock Creek after specific time periods of pumping. For example, using figure 18, if well $115-31 \mathrm{E}-$ $21 A D C l$, located 520 ft $(0.1 \mathrm{mi})$ from Rock Creek, were pumped for 80 days at $1,100 \mathrm{gal} / \mathrm{min}$, then at the end of that time, 70 percent of the water pumped would be derived from the stream. The values of $T$ and $S$ used to draw the curves in figure 18 are thought to be representative of the Tertiary sedimentary-rock aquifer in Rockland basin. If the well pumped $1,100 \mathrm{gal} / \mathrm{min}$, it would, after 80 days, deplete Rock Creek flow by about $1.7 \mathrm{ft} 3 / \mathrm{s}$. As pumping time approached infinity, the volume of stream depletion would approach the volume pumped. After pumping ceased, the 
EXPLANATION
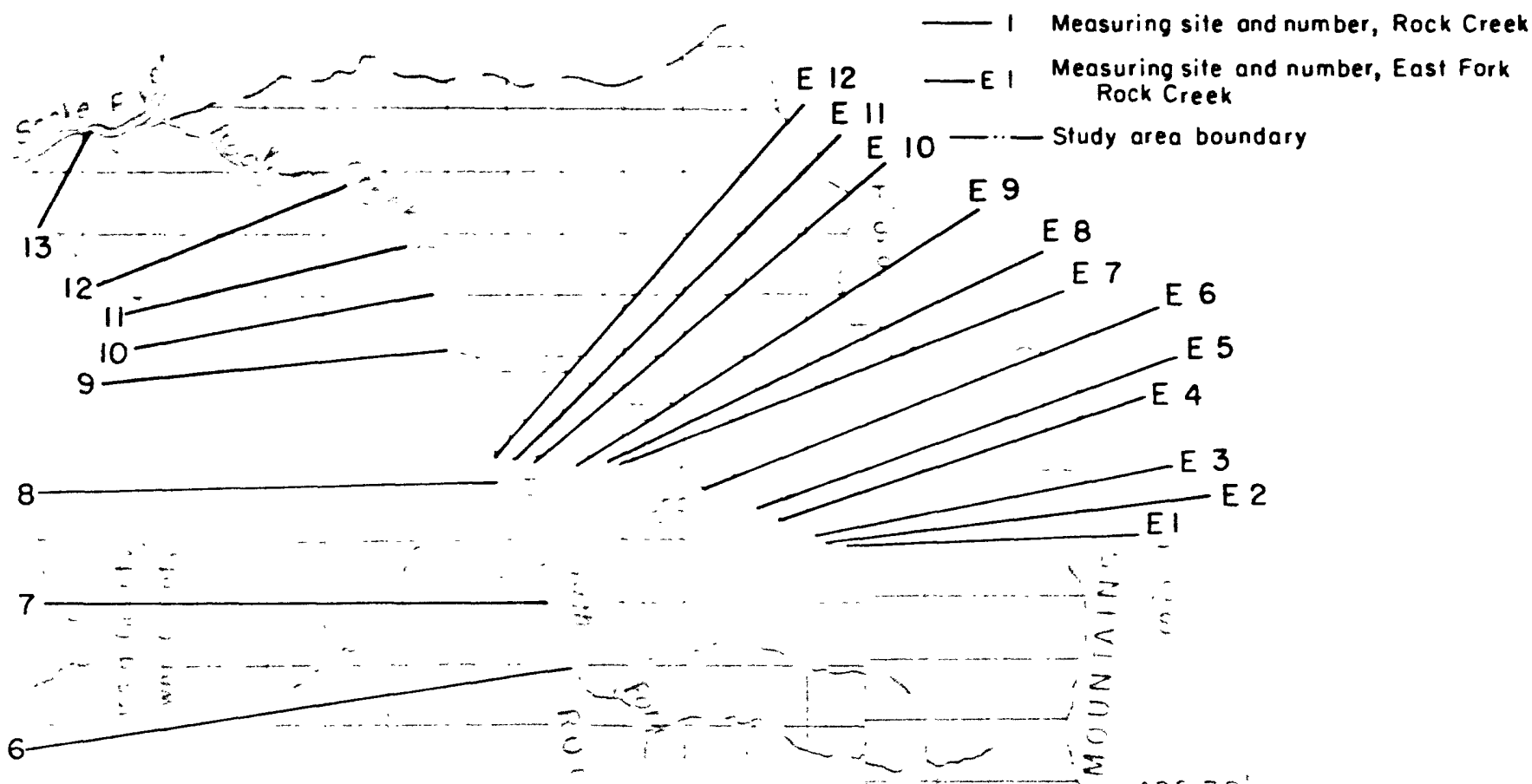

5
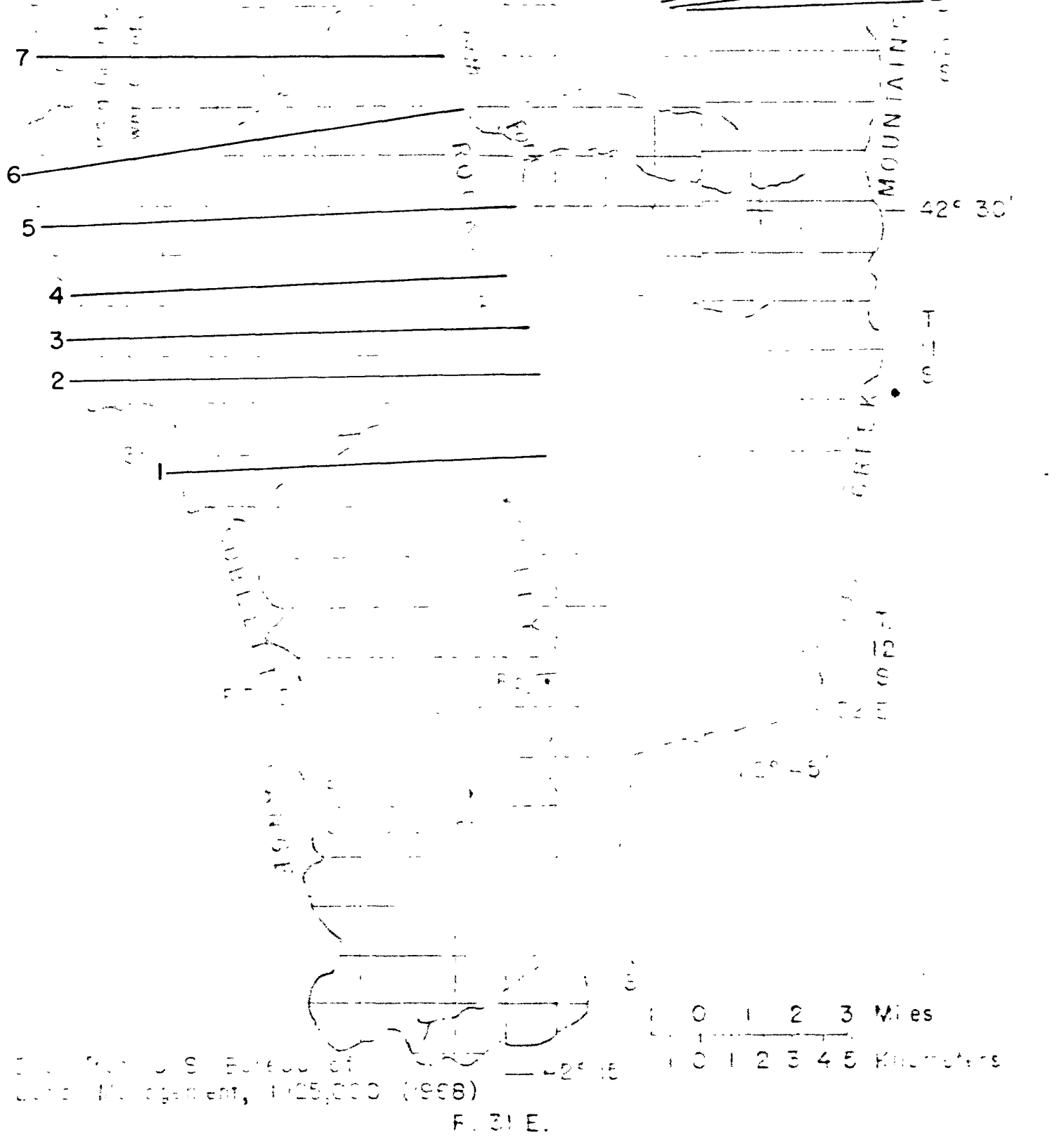

Figure 17.--Discharges and locations 


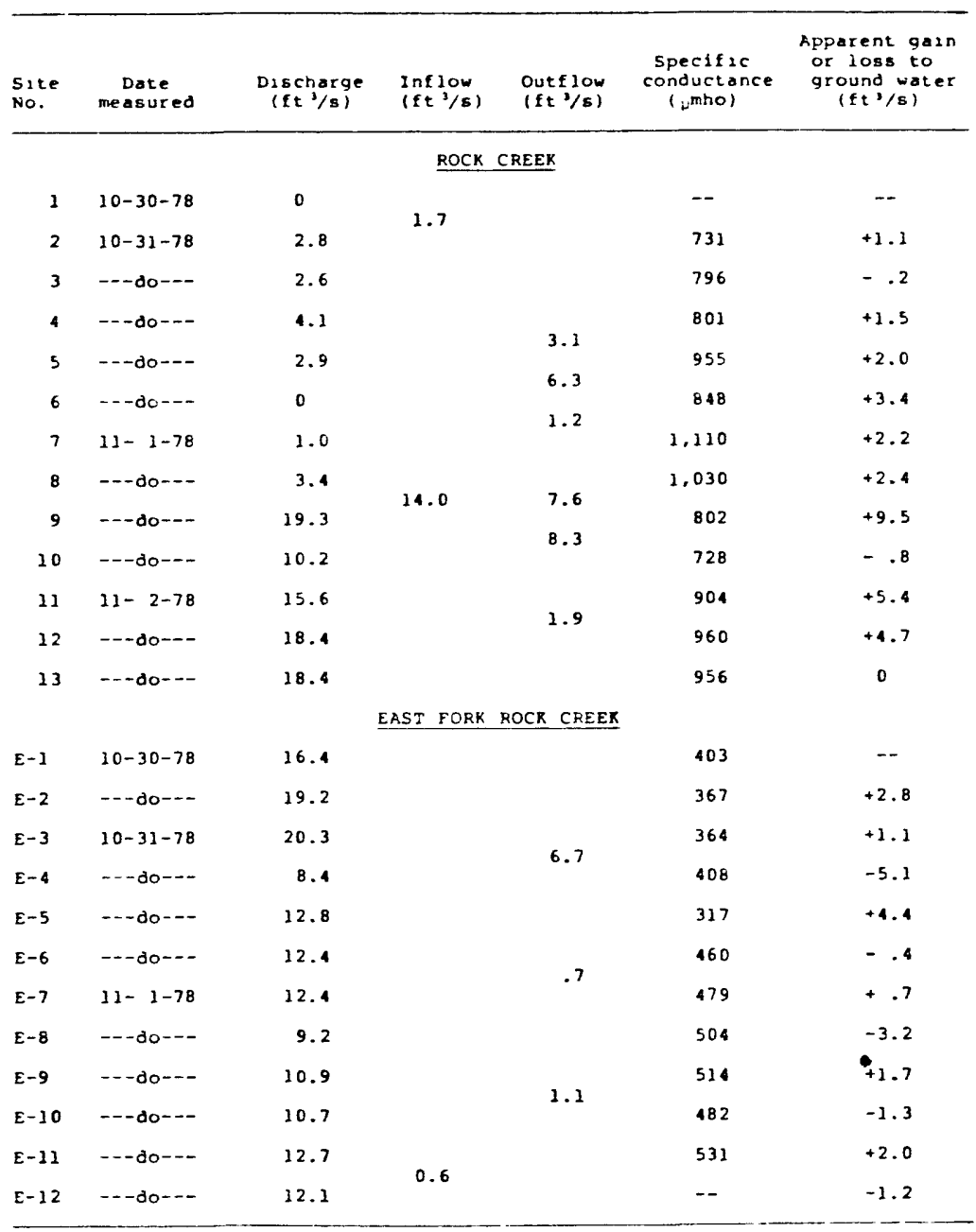
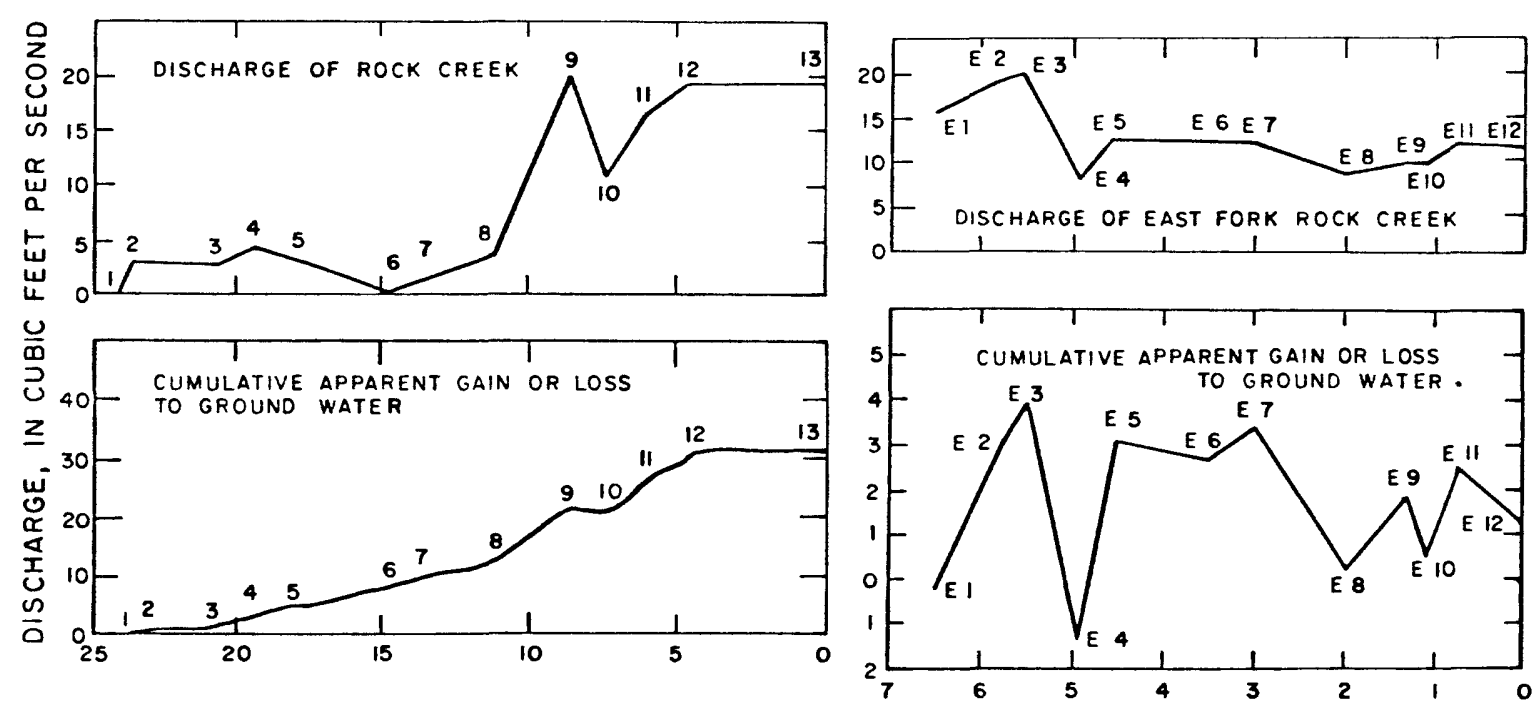

DISTANCE, IN RIVEF MILES ABOVE MOUTH 


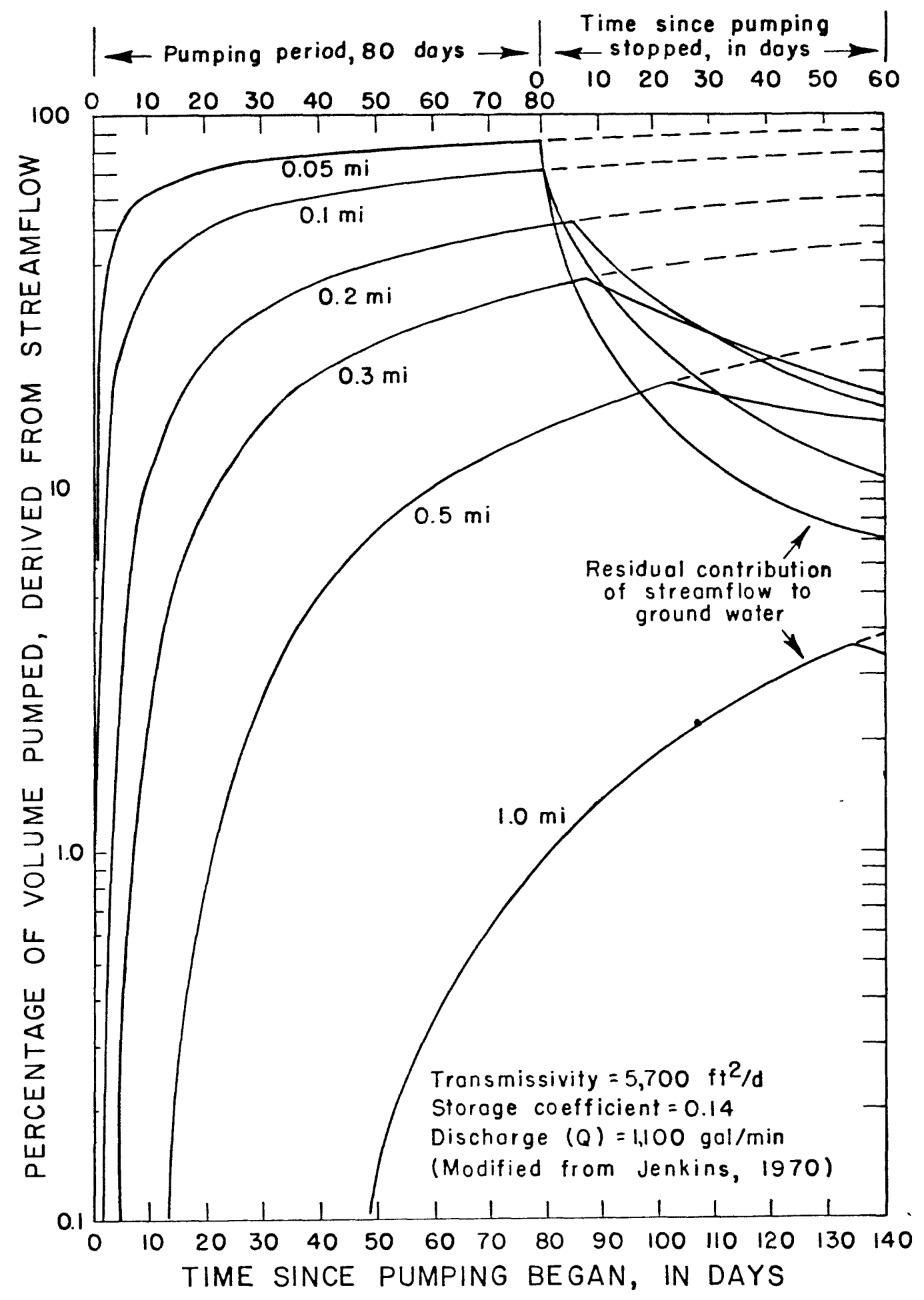

Figure 18. - Effects of ground-water pumpage on streomflow of selected distances from Rock Creek. 
stream would continue to lose water to the ground-water system until equilibrium again was achieved. Residual effects on stream depletion (shown as "time since pumping stopped" in fig. 18) are smaller for a well closer to the stream.

Normally, the volume of depleted ground water would be replenished during periods of recharge unless (1) depletion greatly exceeded available recharge, (2) residual and lag effects were too lengthy for recovery to occur, or (3) storage was drawn through a less permeable boundary than that used in this analysis.

\section{Ground-Water Recharge From Floods}

Short periods of recharge to the aquifer can occur from a sudden increase in streamflow during floods. The rate of ground-water recharge can be estimated by using a method developed by Rorabaugh (1964), provided the magnitude of the water-table rise associated with the flood and the $T$ and $S$ of the aquifer are known. Using Rorabaugh's method, the water table is assumed to be horizontal (everywhere at stream level) and to extend the width of the valley. The true configuration of the water table limits applicability of the method but does allow consideration of maximum effects of recharge.

Assuming a typical sudden recharge impulse in observation well 11S-31E-21ADDl (fig. 15) caused by runoff in Rock Creek, the aquifer would be recharged by a certain unit discharge per foot of channel length. Using the aquifer characteristics computed previously ( $T$ and $S$ values of 5,700 $\mathrm{ft}^{2} / \mathrm{d}$ and 0.14 , respectively), height of recharge impulse ( $1.5 \mathrm{ft})$, and time since recharge impulse occurred, recharge to channel banks for the first $2 \frac{1}{2}$ days from storm runoff for a 1-mi width strip on each side of Rock Creek would be 55 (gal/d)/ft. This rate is equivalent to a volumetric rate of $9 \mathrm{ft}^{3} / \mathrm{s}$ for $10 \mathrm{mi}$ of channel length. Return discharge to the stream on the recession limb of the observation well hydrograph (fig. 15) for 7.2 days and 38 days would contribute discharges of 2.6 and $0.63 \mathrm{ft}^{3} / \mathrm{s}$, respectively, to 10 $\mathrm{mi}$ of channel length. These discharges would be released from bank storage and would contribute about 7 percent of the existing streamflow at that time. Extending the horizontal water table to include aquifer strips $4.5 \mathrm{mi}$ wide (recharge from the stream to the aquifer is assumed to be horizontal and to terminate at the fault boundaries) bordering the stream gives similar bank-storage release values, which indicates that there is minimal increase in discharge from bank storage at greater distances from the stream. 
Combining Rorabaugh's method with a technique for hydrograph separation (Daniel, 1976, and Daniel, J. F., oral commun., 1980), the total volume of ground water contributed to streamflow from flood-recharge pulses can be calculated. An example of the procedure was outlined by wilder and Simmons (1978). The calculated volume of ground water contributed to streamflow during runoff events, as applied to station 13077500 on Rock Creek for the period 1955-60, is 56 percent of the total flow. Total ground-water contribution to streamflow is estimated to average 79 percent of the annual flow during this same period.

\section{WATER QUALITY}

Water samples for chemical analysis were collected during May and June 1979 at 9 surface-water sites, 13 wells, and 2 springs in Rockland basin. Results of the analyses are given in table 5. Several surface-water sites also were sampled for suspended-sediment concentrations during periods of high flow January 14-16, 1980. Sediment data are shown in table 6 .

\section{Surface water}

The chemical quality of most surface water in the study area is generally good to fair, and, although hard, is suitable for most uses in the basin. Pattern diagrams devised by stiff (1951) in figure 19 depict chemical differences and similarities among selected waters sampled during this study.

Surface water, represented by hatchured patterns in figure 19, is generally a calcium bicarbonate type. In the vicinity of Rock Creek below Rockland, the water is higher in dissolved magnesium and probably is derived from ground-water discharge from the aquifer to the stream. Most surface water in the study area is classified (Wilcox, 1955) as either hard (120-180 $\mathrm{mg} / \mathrm{L}$ calcium carbonate) or very hard (more than $180 \mathrm{mg} / \mathrm{L}$ calcium carbonate).

During the study of streamflow gains and losses, 21 sites on Rock Creek and 16 sites on East Fork Rock Creek were sampled for specific conductance (fig. 17). An appraisal of the data shows that as the proportion of groundwater discharge to the stream increases, the specific conductance also increases, indicating that water from the aquifer is higher in dissolved solids. When streams receive a large proportion of direct runoff from snowmelt and precipitation, the specific conductance rapidly decreases. 


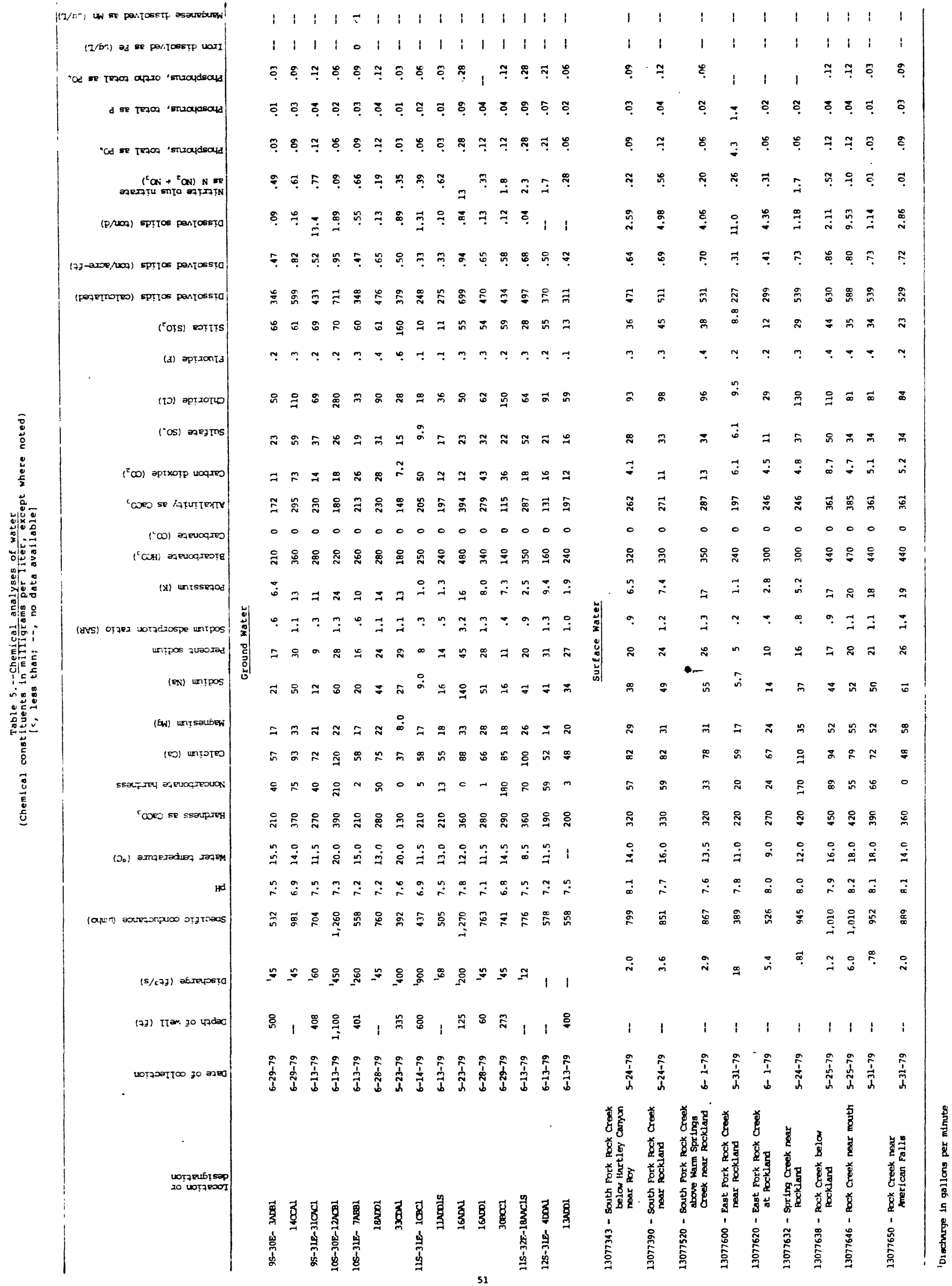




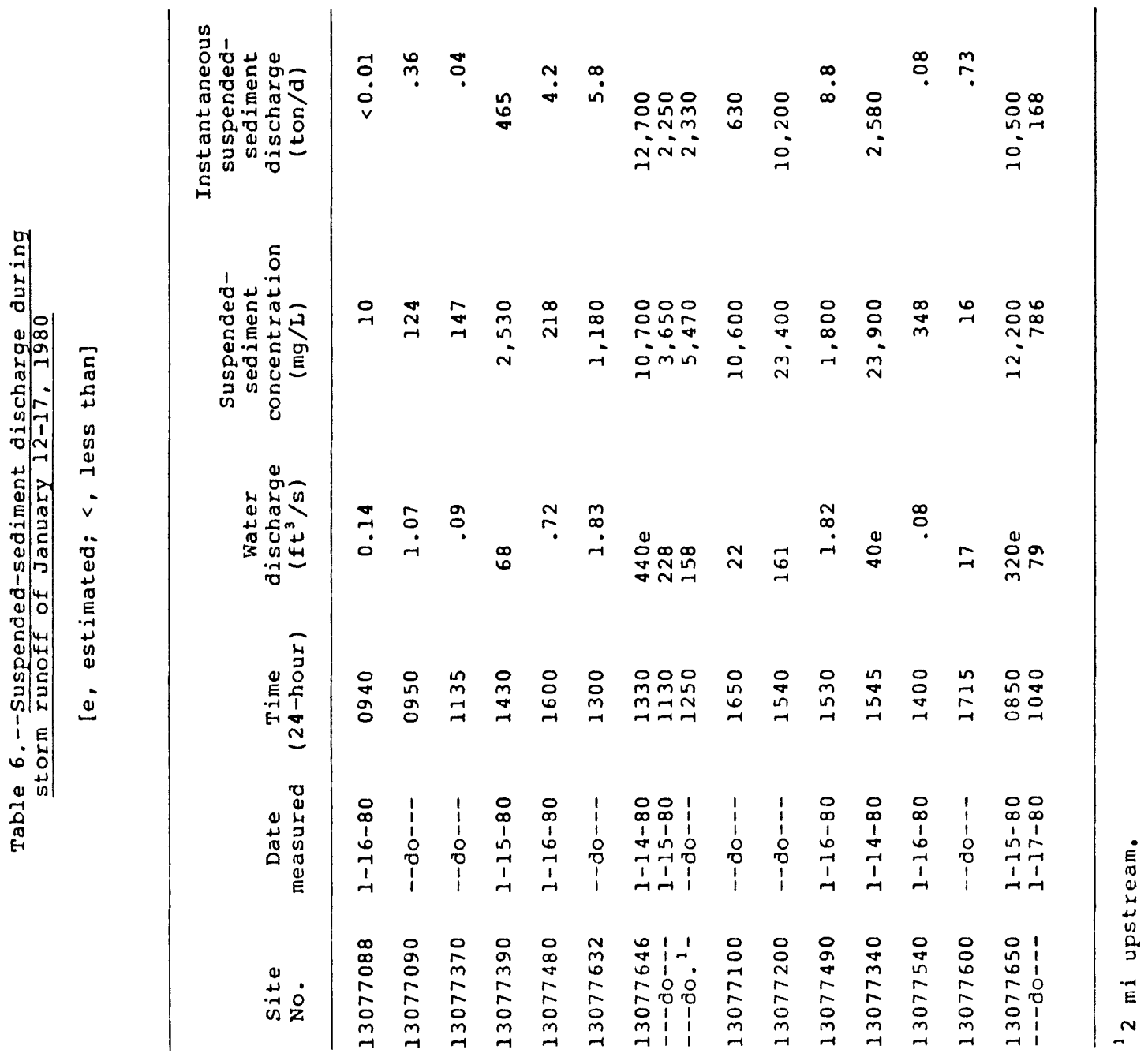




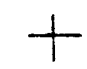

\section{EXPLANATION}

Pottern diagram

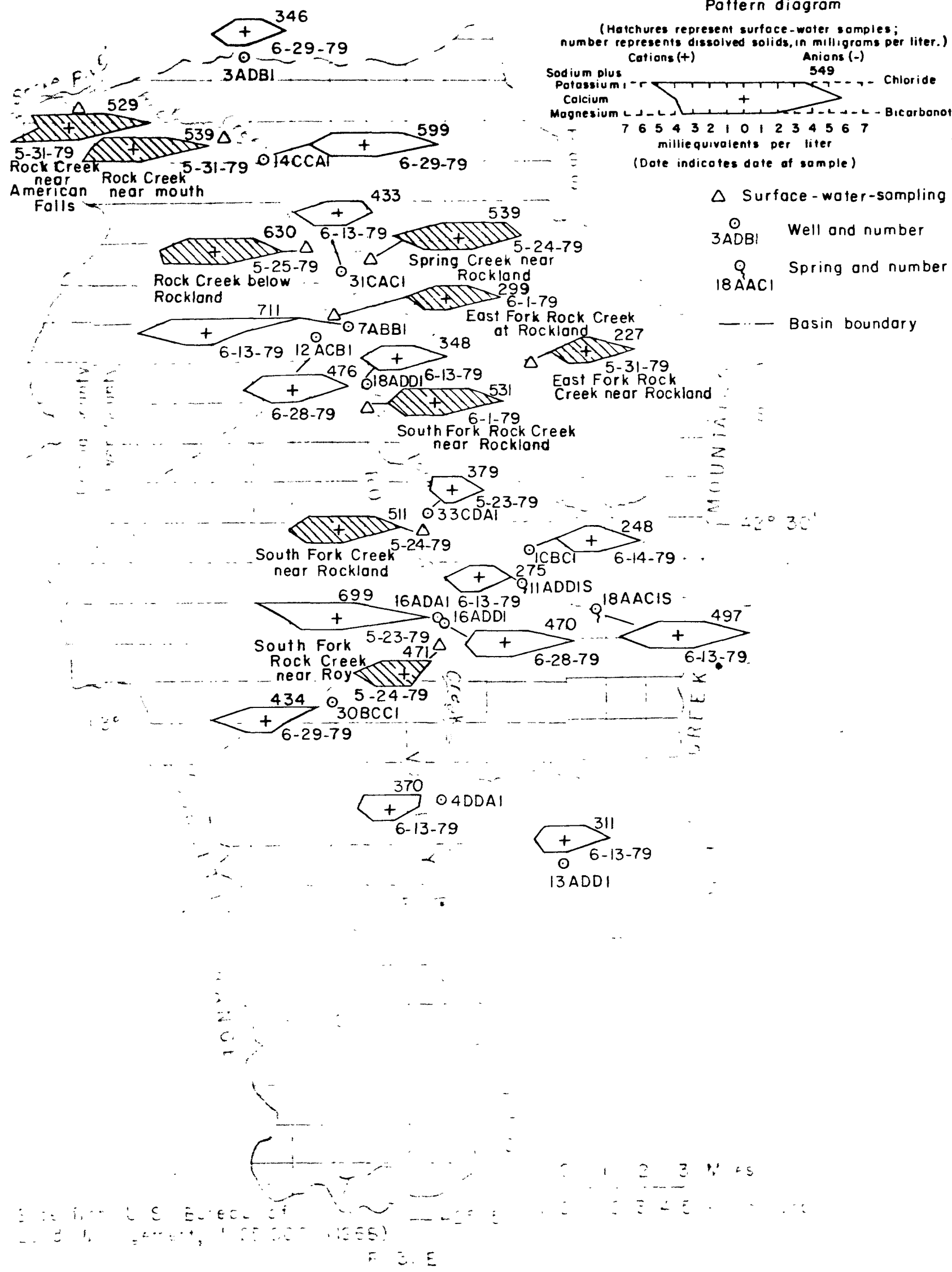

Figure 19.. Chemical character of woter. 
On the basis of specific-conductance values and SAR (sodium-adsorption ratio), surface water also was classified to determine its suitability for irrigation. All surface water in the study area is within the low sodium water classification and can be used on most soils with little danger of developing harmful levels of exchangeable sodium. Some sodium-sensitive crops may be affected (Wilcox, 1955, p. 10). Except for East Fork Rock Creek, surface water in Rockland basin is classified as moderately high in salinity hazard. These waters should not be used on soils that have restricted drainage or on plants that have low salt tolerance. Plants that have moderate salt tolerance can be grown in most places without special practices of salinity control. Even with adequate drainage, special management for salinity control may be required.

Water samples were collected during January 14-17, 1980, for determination of suspended-sediment concentrations (table 6). At this time, stream discharges were at a maximum, and numerous tributaries were at bankfull or overflow stage. Most of the stream channels had eroded their banks when the measurement sites were revisited in mid-June 1980 .

Concentrations of suspended sediment resulting from soil losses in a dominantly agricultural area are expected to be high when floods occur (table 6). Removal of protective vegetation and various land-surface disturbances by man's activities can cause increased erosion. •

\section{Ground Water}

The relative abundance of the common ions in ground water from each well sampled during this study is shown in figure 19. Calcium and bicarbonate are the predominant ions. The concentration of dissolved solids for most samples is generally less than $700 \mathrm{mg} / \mathrm{L}$. The diagrams in figure 19 show that ground waters throughout the basin are generally similar and vary little in types and amounts of dissolved constituents.

Several of the apparently anomalous water-quality analyses shown in figure 19 can be explained by their relation to specific sources. For example, the water sample from well $10 \mathrm{~S}-30 \mathrm{E}-12 \mathrm{ACB}$ is higher in calcium, potassium, and chloride than other water samples. This well pumps water from aquifers composed chiefly of sedimentary materials high in these constituents. 
A ground-water sample also may be influenced by return irrigation flows. Accumulated salts that infiltrate through or are leached from the soil eventually may mix with ground water. An example is the water sample taken from well 11S-3IE-16ADAl, a shallow well in an area where the water table is about $7.5 \mathrm{ft}$ below land surface. This sample was higher in sodium, alkalinity, and dissolved solids than other water samples. The potential exists that saline or alkaline salts from evaporation of ground-water derived irrigation waters could result in local, unproductive acreage. On the basis of specific conductance and SAR, ground waters are, with the exception of the two wells previously discussed, classified as medium salinity waters, which can be used if a moderate amount of leaching occurs.

Ground-water samples can be influenced by nonagricultural uses; for example, the high concentration of nitrates and nitrites at well $11 \mathrm{~s}-31 \mathrm{E}-16 \mathrm{ADAl}$ is attributed to contamination by seepage from nearby livestock corrals.

\section{SUGGESTIONS FOR MONITORING}

To provide data for managing water resources in Rockland basin, the following network to monitor ground-water level fluctuations, surface-water discharge, and waterquality changes is suggested:

Continue bimonthly water-level measurements at the following observation wells: 10S-31E-5DADI; 10S-3IE-29BBAl; 12S-3lE-22BCCl. Also, make bimonthly water-level measurements in well 10S-30E-25BAAl or lOS-30E-24CDDl. Retain stream-gaging site at the mouth of Rock Creek to provide surface-water outflow data for Rock Creek. Collect waterquality samples above and below the confluence of East Fork Rock Creek and Rock Creek in the spring and fall. It is further suggested that selected domestic and stock water wells completed in sedimentary deposits near Rockland and Rock Creek be sampled to detect possible localized contaminants, and that East Fork Rock Creek near Rockland be sampled monthly from June to september for bacteria and nutrients to insure the data necessary to analyze quality of surface flow.

\section{SUMMARY}

Total water yield available to Rockland basin is about 5.0 in. $(85,000$ acre-ft/yr $)$ of the 17.3 in. of estimated annul precipitation. Water yields to the Tertiary and 
pre-Tertiary sedimentary rocks range from 0.5 to 10.4 in./yr, respectively. ET is estimated to range from 9.8 to $17 \mathrm{in./yr}$, depending, in part, on altitude.

Major water-bearing rocks in Rockland basin are the Quaternary-Tertiary volcanic rocks, Holocene alluvium, and Tertiary sedimentary rocks. Ground water occurs under water-table conditions, except where locally confined. The principal source of recharge to the basin is precipitation on the fractured and faulted pre-Tertiary sedimentary rocks bordering Rockland basin. Ground water discharges from eastern mountain springs to maintain perennial streamflow. Ground-water movement is generally northward. Near the mouth of Rock Creek, an estimated 51,000 acre-ft/yr of underflow leaves the basin by moving through the basalt to the snake River.

East Fork Rock Creek is the largest surface-water source for irrigation within the basin. Annual discharge for the 1979 water year was 12,900 acre-ft, and for the 1980 water year was 13,700 acre-ft. Surface-water runoff from all available sources is estimated to average 16,500 acre-ft/yr. Annual surface-water discharge from Rockland basin was 19,800 acre-ft during 1979 and 28,900 acre-ft during 1980. Overland runoff and subsequent channel erosion caused particularly high sediment yields during the storm of January 12-17, 1980 .

If the consumptive uses of water for 1979 are considered typical for a normal year, then only 18 percent of the 86,400 acre-ft of total water yield of the basin is currently used. Hypothetically, a portion of the 70,800 acre-ft/yr unused outflow could be captured. In addition to the 51,000 acre-ft/yr of ground-water underflow, 13,000 of the 19,800 acre-ft/yr of surface-water outflow was contributed from ground-water sources. Lowering stream water levels by ground-water pumping could salvage a portion of this water.

However, any additional increase in ground-water withdrawals above current pumpage levels must be strategically placed so as not to interfere with streamflow required to meet existing water rights.

Consumptive use of water for irrigation, municipal, domestic, and stock supplies was estimated to be about 16,000 acre-ft in 1979. Of the total, about 3,500 acre-ft was supplied by ground water. 
Excessive pumping from wells near streams may reduce base flow where the stream and Holocene alluvium and Tertiary sedimentary-rock aquifers are hydraulically connected. Pumping from wells drilled along faults, especially in the headwaters area of East Fork Rock Creek, may affect groundwater movement and diminish flow in nearby springs. Any implied dewatering and water-table declines on a regional basis are speculative, due to lack of long-term water-level data. However, the available water-level records and a hydrologic analysis of the basin indicate that significant volumes of water have not been depleted from the groundwater system.

The quality of surface and ground waters in the basin is generally good for irrigation use; salinity levels are medium to moderately high. East Fork Rock Creek has the lowest concentration of most constituents used in irrigation classification. One ground-water sample taken from a well near a stockyard was high in sodium and nitrates.

Although this study was primarily a general evaluation of the relation between the surface- and ground-water systems in Rockland basin, a more concise treatment of the response of the unconfined aquifer due to effect of increased irrigation withdrawals perhaps can best be understood on a regional scale by simulation analysis using a hydrologic model. The advantage of developing such a model is the ability to predict future cause-and-effect relations. Any proposed management practices and limitations can be evaluated effectively by programming any system of recharge, pumping patterns, and ET losses. 
Balmer, D. K., and Noble, J. B., 1979, water resources of the Fort Hall Indian Reservation, Fort Hall, Idaho: Shoshone, Idaho, p. 94-126.

Bentall, Ray, compiler, 1963, Methods of determining permeability, transmissibility, and drawdown: U.S. Geological Survey Water-Supply Paper 1536-I, 341 p.

Bond, J. G., compiler, 1978, Geologic map of Idaho: Moscow, Idaho, Idaho Bureau of Mines and Geology, I sheet, $1: 500,000$.

Boulton, N. S., 1964, Discussion of analysis of data from non-equilibrium pumping tests allowing for delayed yield from storage: London, Institute of Civil Engineers, Proceedings, v. 28, p. 603-610.

Burnham, W. L., and others, 1966, Summary of ground-water conditions in Idaho, 1966: Idaho Department of Reclamation, water Information Bulletin no. $1,64 \mathrm{p}$.

Clebsch, Alfred Jr., waite, H. A., and Decker, S. O., 1974, The availability of water in the Little Lost River basin, Idaho: Idaho Department of Water Resources, Water Information Bulletin no. $37,60 \mathrm{p}$.

Cooper, H. H. Jr., and Jacob, C. E., 1946, A generalized graphical method for evaluating formation constants and summarizing well-field history: American Geophysical Union Transactions, v. 27, no. 4, p. 526-534.

Crosthwaite, E. G., Thomas, C. A., and Dyer, K. L., 1970, Water resources in the Big Lost River basin, southcentral Idaho: U.S. Geological Survey Open-File Report, $109 \mathrm{p}$.

Dalrymple, Tate, and Benson, M. H., 1967, Measurement of peak discharge by the slope area method: U.S. Geological Survey Techniques of Water-Resources Investigations, Book 3, Chapter A2, 12 p.

Daniel, J.F., 1976, Estimating evapotranspiration from streamflow records: Water Resources Research, June 1976 , p. $360-364$.

Decker, S. O., and others, 1970, Miscellaneous streamflow measurements in Idaho, 1894-1967: U.S. Geological Survey Basic-Data Release, 309 p. 
Dion, N. P., 1969, Hydrologic reconnaissance of the Bear River basin in southeastern Idaho: Idaho Department of Reclamation, water Information Bulletin no. 13, 66 p.

Doty, R. D., and Johnston, R. S., 1969, Comparison of gravimetric measurements and mass transfer computations of snow evaporation beneath selected vegetation canopies: Proceedings, western snow Conference, 4 p.

Fenneman, N. M., 1931, Physiography of the Western United States: New York, McGraw-Hill Book Co., Inc., 534 p.

Idaho state Tax Commission, 1979, Thirty-fifth annual report: Boise, Idaho, p. 43-45.

Jenkins, C. T., 1970, Computation of rate and volume of stream depletion by wells: U.S. Geological Survey Techniques of Water-Resources Investigations, Book 4, Chapter $\mathrm{Dl}, 17 \mathrm{p}$.

Kjelstrom, L. C., and Moffatt, R. L., 198I, A method of estimating flood-frequency parameters for streams in Idaho: U.S. Geological Survey Open-File Report $81-909,99 \mathrm{p}$.

Lohman, S. W., 1979, Ground-water hydraulics: U.S. Geological Survey Professional Paper $708,70 . p$.

Meisler, Harold, 1958, Preliminary report on ground water in the Bonanza Lake area, Power and Blaine counties, Idaho: U.S. Geological Survey Open-File Report, 32 p.

Mundorff, M. J., 1967, Ground water in the vicinity of American Falls Reservoir, Idaho: U.S. Geological Survey Water-Supply Paper 1846 , 58 p.

Mundorff, M. J., Crosthwaite, E. G., and Kilburn, Chabot, 1964, Ground water for irrigation in the Snake River basin in Idaho: U.S. Geological Survey Water-Supply Paper 1654, $224 \mathrm{p}$.

Nace, R. L., and others, 1961, Water resources of the Raft River basin, Idaho-Utah: U.S. Geological Survey Water-Supply Paper 1587, $138 \mathrm{p}$.

Nichols, W. D., 1979, Simulation analyses of the unconfined aquifer, Raft River geothermal area, Idaho-Utah: U.S. Geological Survey Water-supply Paper 2060,46 p. 
Norvitch, R. F., and Larson, A. L., 1970, A reconnaissance of the water resources in the Portneuf River basin, Idaho: Idaho Department of Reclamation, Water Information Bulletin no. $16,56 \mathrm{p}$.

Piper, A. M., 1924, Possibilities of petroleum in Power and Oneida Counties, Idaho: Moscow, Idaho, Idaho Bureau of Mines and Geology, 24 p.

Pluhowski, E. J., 1970, Hydrology of the upper Malad River basin, southeastern Idaho: U.S. Geological survey Water-supply Paper 1888, $89 \mathrm{p}$.

Riggs, H. C., 1969, Mean streamflow from discharge measurements: International Association of Scientific Hydrology Bulletin, v. 14, no. 4, p. 95-110.

Rorabaugh, M. I., 1964, Estimating changes in bank storage and ground-water contribution to streamflow: International Association of Scientific Hydrology Publication 63 , p. 432-441.

Rosa, J. M., 1968, Water-yield maps for Idaho: Moscow, Idaho, U.S. Department of Agriculture, $15 \mathrm{p}$.

Stewart, J. W. , Nace, R. L., and Deutsch, Morris, 1951, Preliminary report on ground water in the Michaud Flats project, Power County, Idaho: U.S. Geological Survey Open-File Report, $44 \mathrm{p}$.

Stiff, H. A. Jr., 1951, The interpretation of chemical analyses by means of patterns: Petroleum Technical Journal, Technical Note 84 , sec. 1 , p. 15-16.

Sutter, R. J., and Corey, G. L., 1970, Consumptive irrigation requirements for crops in Idaho: Moscow, Idaho, University of Idaho, $97 \mathrm{p}$.

Theis, C. V., 1963, Estimating the transmissibility of a water-table aquifer from the specific capacity of a well, in Bentall, Ray, compiler, Methods of determining permeability, transmissibility, and drawdown: U.S. Geological Survey Water-Supply Paper 1536-I, p. 332336 .

Thomasson, H. G., Olmsted, F. H., and LeRoux, E. F., 1960, Geology, water resources, and ground-water storage capacity of part of Solano County, California: U.S. Geological Survey Water-Supply Paper $1464,693 \mathrm{p}$. 
Trimble, D. E., and Carr, W. J., 1976, Geology of the Rockland and Arbon quadrangles, Power County, Idaho: U.S. Geological Survey Bulletin 1399, 115 p.

U.S. Bureau of the Census, 1942, Irrigation of agricultural lands, Idaho, 1940: Washington, U.S. Government Printing Office, 43 p.

1952, U.S. census of agriculture, 1950: Washington, U.S. Government Printing Office, v. 1 , pt. 28,188 p.

1952, U.S. census of agriculture, 1952: Washington, U.S. Government Printing Office, v. 3, pt. 6, 53 p.

1961, U.S. census of agriculture, 1959: Washington, U.S. Government Printing Office, v. 1, pt. 39, 197 p.

1966, U.S. census of agriculture, Power County, Idaho, Washington, U.S. Government Printing Office, 6 p. 1974, U.S. census of agriculture, 1974: Washington, U.S. Government Printing office, v. 4, p. 235-239.

U.S. Department of Agriculture, 1955, The yearbook of agriculture: Washington, U.S. Government Printing Office, $751 \mathrm{p}$.

1971, Irrigation water requirements: Washington, U.S. Government Printing Office, 88 p.

1979, Idaho county estimates: Boise, Idaho, Idaho Crop and Livestock Reporting Service.

U.S. Geological Survey, 1972, water resources data for Idaho, Part 2, water quality records: Washington, U.S. Government Printing Office, $243 \mathrm{p}$.

U.S. Salinity Laboratory Staff, 1954, Diagnosis and improvement of saline and alkali soils: U.S. Department of Agriculture Handbook 60,160 p.

U.S. Soil Conservation Service, 1967, Irrigation water requirements: Washington, U.S. Government Printing Office, $88 \mathrm{p}$.

Walker, E. H., Dutcher, L. C., Decker, S. O., and Dyer, K. L., 1970, The Raft River basin, Idaho-Utah as of 1966: Idaho Department of Water Administration, water Information Bulletin no. 19, 95 p. 
Walton, W. C., 1962, Selected analytical methods for well and aquifer evaluation: Urbana, IIl., Illinois State Water Survey, Bulletin $49,81 \mathrm{p}$.

West, A. J., 1962, Snow evaporation from a forested watershed in the central Sierra Nevada: Journal of Forestry, v. 60, no. 7, p. 481-484.

West, S. W., and Kilburn, Chabot, 1963, Ground water for irrigation in part of the Fort Hall Indian Reservation, Idaho: U.S. Geological Survey Water-Supply Paper $1576-\mathrm{D}, 33 \mathrm{p}$.

Wilcox, L. V., 1955, Classification and use of irrigation waters: U.S. Department of Agriculture Circular 969, $19 \mathrm{p}$.

Wilder, H. B., and Simmons, C. E., 1978, Program for evaluating stream quality in North Carolina: U.S. Geological Survey Circular 764, 16 p.

Williams, G. R., and others, 1940, Natural water loss in selected drainage basins: U.S. Geological Survey Water-Supply Paper 846,62 p.

Young, H. W., and Harenberg, W. A., 1971, Ground-water pumpage from the Snake Plain aquifer, southeastern Idaho: Idaho Department of Water Administration, Water Information Bulletin no. 23,28 p. 